\title{
Physiological Substrates and Ontogeny-Specific Expression of the Ubiquitin Ligases
}

2

3

4 Patrick Schriek ${ }^{1}$, Haiyin Liu ${ }^{1}$, Alan C. Ching ${ }^{1}$, Pauline Huang ${ }^{1}$, Nishma Gupta ${ }^{1}$, Kayla R.

5 Wilson ${ }^{1}$, MinHsuang Tsai ${ }^{1}$, Yuting Yan ${ }^{2}$, Christophe F. Macri ${ }^{1}$, Laura F. Dagley ${ }^{3,4}$, Giuseppe

6 Infusini ${ }^{3,4}$, Andrew I. Webb ${ }^{3,4}$, Hamish McWilliam ${ }^{1,2}$, Satoshi Ishido ${ }^{5}$, Justine D. Mintern ${ }^{1}$ and

7 Jose A. Villadangos ${ }^{1,2}$

8

$9{ }^{1}$ Department of Biochemistry and Pharmacology, Bio21 Molecular Science and Biotechnology

10 Institute, The University of Melbourne, Parkville, VIC 3010, Australia.

$11{ }^{2}$ Department of Microbiology and Immunology, Peter Doherty Institute for Infection and

12 Immunity, The University of Melbourne, Parkville, VIC 3010, Australia.

$13{ }^{3}$ Advanced Technology and Biology Division, The Walter and Eliza Hall Institute of Medical 14 Research, Parkville, VIC 3052, Australia.

$15{ }^{4}$ Department of Medical Biology, University of Melbourne, Parkville, VIC 3010, Australia.

$16{ }^{5}$ Department of Microbiology, Hyogo College of Medicine, 1-1 Mukogawa-cho, Nishinomiya 1717 663-8501, Japan

18

21 Correspondence to

Justine D. Mintern (jmintern@unimelb.edu.au) or
Jose A. Villadangos (j.villadangos@unimelb.edu.au) 


\section{ABSTRACT}

24 MARCH1 and MARCH8 are ubiquitin ligases that control the expression and trafficking of

25 critical immunoreceptors. Understanding of their function is hampered by three major 26 knowledge gaps: (i) it is unclear which cell types utilize these ligases; (ii) their level of 27 redundancy is unknown; and (iii) most of their putative substrates have been described in cell 28 lines, often overexpressing MARCH1 or MARCH8, and it is unclear which substrates are 29 regulated by either ligase in vivo. Here we address these questions by systematically analyzing 30 the immune cell repertoire of MARCH1- or MARCH8-deficient mice, and applying unbiased 31 proteomic profiling of the plasma membrane of primary cells to identify MARCH1 and 32 MARCH8 substrates. Only CD86 and MHC II were unequivocally identified as 33 immunoreceptors regulated by MARCH1 and MARCH8, but each ligase carried out its 34 function in different tissues. MARCH1 regulated MHC II and CD86 in professional and 35 "atypical" antigen presenting cells of hematopoietic origin, whereas MARCH8 only operated 36 in non-hematopoietic cells. Our results reveal that the range of cells constitutively endowed 37 with antigen-presentation capacity is wider than generally appreciated. They also establish 38 MARCH1 and MARCH8 as specialized regulators of CD4+ T cell immunity in two 39 ontogenically distinct cellular compartments. 
41 Ubiquitination is a major mechanism for the regulation of membrane proteostasis. In brief, covalent attachment of ubiquitin ( $\mathrm{Ub}$ ) chains to the cytosolic tail of transmembrane proteins promotes endosomal trafficking to multivesicular bodies for subsequent degradation in lysosomes [1]. This post-translational modification enables the fine-tuning of surface protein expression levels. Ub is attached to substrates by E3 Ub ligases. Membrane Associated RING$\mathrm{CH}$ Finger (MARCH, gene symbol Marchf) is a family of eleven E3 ligases, all of which possess two or more transmembrane domains, with the exception of MARCH7 and MARCH10 [2]. They were initially identified as the mammalian homologues of herpesvirus immunoevasins that ubiquitinate host molecules involved in anti-viral immunity to subvert immune responses [3][4]. MARCH E3 Ub ligases are thought to be specialized at ubiquitinating immunoregulatory receptors, but their physiological substrates remain largely unknown [2][5]. It is also unclear if their expression and function is restricted to cells of the immune system and, if so, which.

MARCH1 and MARCH8 are the most studied members of the MARCH family. As they share approximately $60 \%$ overall sequence homology [2], they are thought to also share substrate specificity. Indeed, both ubiquitinate major histocompatibility complex class II (MHC II) molecules, the receptor employed by antigen presenting cells (APC) to display peptide antigens to $\mathrm{CD}^{+} \mathrm{T}$ cells. By regulating MHC II expression [6][7][8], MARCH1 and MARCH8 play key roles in $\mathrm{CD}^{+} \mathrm{T}$ cell development in the thymus [9][10][11] and activation in the periphery [12], respectively. Furthermore, they have been involved in complex immune reactions such as inflammation [13], immunity to infection [14][15], cancer [16], allergy and autoimmunity [17][18]. This poses the question whether both ligases regulate the expression of other immune receptors, some of which reportedly include CD44 [19], CD71 [20], CD86 [21], CD95 [22] and CD98 [19] among others [5][23]. However, to date CD86 is the only membrane protein apart from MHC II that has been shown to be regulated by MARCH1 in vivo [21], and it is not known if it can also be regulated by MARCH8. All other putative MARCH1 or MARCH8 substrates have been described in cell lines and/or overexpression studies. MARCH proteins are expressed at very low levels in primary cells [2][24][25][26], and since E3 ligase overexpression can cause off-target effects, it remains unclear which, if any of the MARCH1 and MARCH8 substrates described in transfected cell lines are ubiquitinated by these ligases

72 in physiological settings. To summarize, the repertoire of MARCH1 and MARCH8 substrates in vivo remains largely unknown. This is an important shortcoming because ubiquitination is 
74 amenable to pharmacological manipulation [27][28], and development of drugs targeting 75 MARCH1 or MARCH8 might have therapeutic potential provided their substrates are 76 identified.

77

78 Another important knowledge gap in MARCH1 and MARCH8 biology pertains to their 79 expression pattern. Quantitating MARCH1 or MARCH8 protein expression is unfeasible due 80 to their low abundance [2] and fast turn-over [29][30], and even their transcription levels are poor predictors of function [24][25][26]. Identification of MARCH1- or MARCH8-expressing cells thus relies on analysis of surface expression of membrane protein substrates as a surrogate of activity. MARCH1 ubiquitinates MHC II and CD86 in B cells and conventional and

84 plasmacytoid dendritic cells (cDC and pDC, respectively) [6][7][8], but it is not functional in 85 thymic epithelial cells (TEC) [9][10]. Whether it is active in other hematopoietic or non86 hematopoietic cells remains unknown. In contrast, MARCH8 ubiquitinates MHC II in TEC, 87 not in B cells or DC [9][10], but it is not known if it ubiquitinates other receptors in these cells, 88 and whether it is also expressed in other cells. Incomplete understanding of the pattern of MARCH expression again limits the development and potential application of ubiquitinationmodulating agents as immunomodulatory drugs.

92 Here, we present a systematic analysis of the pattern of activity of MARCH1 and MARCH8 in 93 multiple hematopoietic and non-hematopoietic cells isolated from Marchf1 $^{-/-}$and Marchf8-- $^{-/}$ 94 mice. We have also carried out quantitative proteomic comparisons of WT vs Marchf1 ${ }^{-/-}$or 95 Marchf $^{-/-}$plasma membrane purified from cDC and B cells. Our results define physiological 96 substrates regulated by these two ligases and demonstrate functional specializations of 97 MARCH1 and MARCH8 in two ontogenically distinct compartments. 
MATERIALS AND METHODS

Mice

100

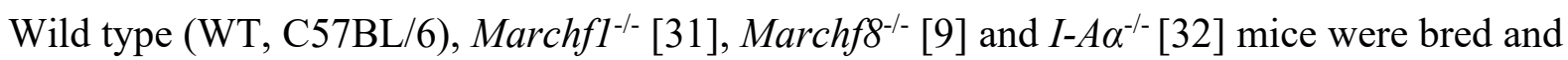
maintained in specific pathogen-free conditions within the Melbourne Bioresources Platform at the Bio21 Molecular Science and Biotechnology Institute. Analyses were undertaken with male or female mice aged between 6-14 weeks and performed in accordance with the Institutional Animal Care and Use Committee guidelines of the University of Melbourne. All procedures were approved by the Animal Ethics Committee at the University of Melbourne.

\section{Isolation of mouse primary cells and analytical flow cytometry}

108 Single cell suspensions from blood, spleen, subcutaneous lymph nodes (LN), thymus, 109 peritoneal cavity and lung were generated for analysis of B cells, T cells, DC, granulocytes, 110 macrophages, monocytes, neutrophils, eosinophils and thymic or alveolar epithelial cells. 111 Blood was collected from submandibular veins and red blood cells were lysed. Whole single 112 cell suspensions from spleen and subcutaneous LN (axillary and inguinal) were generated by 113 spleen digestion with $0.1 \%$ DNase I (Roche) and $1 \mathrm{mg} / \mathrm{ml}$ collagenase type III (Worthington) 114 and red blood cell lysis. DCs from spleen and LN were further enriched by selection of low115 density cells by density gradient centrifugation in $1.077 \mathrm{~g} / \mathrm{cm}^{3}$ Nycodenz ${ }^{\circledR}$ (Axis shield). 116 Thymi were digested in $0.1 \%$ DNase I (Roche) and $0.5 \mathrm{U} / \mathrm{ml}$ liberase (Roche) and thymic cDC 117 were further enriched by $1.077 \mathrm{~g} / \mathrm{cm}^{3}$ Nycodenz ${ }^{\circledR}$ density gradient centrifugation (Axis shield).

118 Cells from the peritoneal cavity were harvested by injection and aspiration of PBS. Lungs were 119 perfused with PBS and digested with $50 \mu \mathrm{g} / \mathrm{ml}$ DNase I (Roche) and $0.25 \mathrm{mg} / \mathrm{ml}$ liberase 120 (Roche) and red blood cells lysed.

122 For flow cytometry, cells were incubated with FcR blocking reagent (Miltenyi Biotec), prior 123 to staining with mAb detecting B220/CD45R (RA3-6B2), CD19 (6D5), CD64 (X54-5/7.1), 124 F4/80 (F4/80, Walter Eliza Hall Institute (WEHI) Antibody Facility), CD3 (KT3-1.1, WEHI 125 Antibody Facility), TCR $\beta$ (H57-597, WEHI Antibody Facility), CD4 (GK1.5), CD8 126 (YTS169.4 WEHI Antibody Facility), CD8 (53-6.7), BST-2 (927), Siglec-H (551), MHC II 127 (M5/114), CD11c (N418), CD11b (M1/70), Ly6G (1A8), Ly6C (HK1.4), NK1.1 (PK136, BD 128 Biosciences), Sirpa (P84), XCR1 (ZET), CD45 (30-F11), EpCAM (G8.8), Ly51 (6C3), UEA1291 (Vector Laboratories), MerTK (2B10C42), Siglec-F (E50-2440 BD Biosciences), CD31 130 (390), CD24 (M1/69, WEHI Antibody Facility), Sca-1 (D7), CD86 (GL-1), CD40 (FGK45.5, 131 Miltenyi Biotec), CD80 (16-10A1, BD Biosciences), CD44 (IM7.81), CD71 (R17217, 
eBiosciences), CD95 (15A7, eBiosciences), CD98 (RL388), PD-L1 (10F.9G2), PD-L2

133 (TY25), ICOS-L (HK5.3), B7-H3 (MIH35) or B7-H4 (HMH4-5G1), conjugated to

134 fluorochromes BUV395, BUV805, FITC, PE, PE-Cy7, PerCP/Cy5.5, APC, APC-Cy7, AF700,

135 BV785, BV650, BV510 or BV421 (all from BioLegend, if not stated differently). Cell viability 136 was determined with Fixable Viability Dye eFluor ${ }^{\mathrm{TM}} 780$ (eBiosciences), propidium iodide (PI) 137 or diamidino phenylindole (DAPI). Analysis was performed using a LSRFortessa (BD 138 Biosciences) or CytoFLEX LX (Beckman Coulter) in the Melbourne Cytometry Platform 139 (University of Melbourne). Data was analyzed with FlowJo (Tree Star) and GraphPad Prism.

140 Supplementary Figures 1 and 2 summarize gating strategies for cells from blood, spleen, 141 subcutaneous lymph nodes (LN), thymus, peritoneal cavity and lung.

142

\section{Isolation of primary immune cells for proteomic analysis.}

144 B cells were purified from spleens using Ficoll ${ }^{\circledR}$ Paque Plus (GE Healthcare) gradient 145 centrifugation and negative depletion with FITC-conjugated mAb specific for CD4 (GK1.5), Ly-76 (TER119) and CD43 (S7) and magnetic anti-FITC MicroBeads (Miltenyi Biotec).

147 Preparations were approximately $95-98 \%$ pure for $\mathrm{CD} 19^{+} \mathrm{B} 220^{+}$B cells. Splenic cDC were

148 purified from mice subcutaneously injected with Flt3L-secreting melanoma cells [33], 9 days

149 before purification. cDC were purified from spleens of Flt3L-expanded mice following spleen

150 digestion with DNase I (Roche) and collagenase type III and Nycodenz ${ }^{\circledR}$ density gradient centrifugation (Axis shield) with subsequent negative depletion using rat mAb specific for CD3 (KT3-1.1), Thy1 (T24/31.7), Ly-76 (Ter119), B220 (RA3-6B2) and Ly-6C/G (RB6-8C5) and anti-rat IgG-coupled magnetic beads (Qiagen) as previously described [34]. Preparations were approximately $90-95 \%$ pure for $\mathrm{CD} 11 \mathrm{c}^{+} \mathrm{MHC} \mathrm{II}^{+} \mathrm{cDC}$.

\section{Preparation of subcellular fractions enriched in plasma membrane and intracellular} compartments for proteomics

158 Subcellular fractionation was performed as previously described [35]. In brief, purified B cells 159 (4-5 x $10^{7}$ cells, $95-98 \%$ purity) and cDC (4-5 x 107 cells, 90-95\% purity) from spleens of WT, $160 \mathrm{Marchf1}^{-/-}$and $\mathrm{Marchf8}^{-/-}$mice were incubated with FITC-conjugated anti-CD19 and anti-B220 $161 \mathrm{mAb}$ (B cells) or anti-CD11c, anti-CD45.2, anti-CD49d and anti-MHC I mAb (cDC). mAb-

162 labelled cells were homogenized in the presence of cOmplete ${ }^{\mathrm{TM}}$ protease inhibitors (Roche) by 163 mechanical disruption using a cell-cracker (HGM Laboratory equipment). Homogenized 164 preparations were centrifuged at low speed to obtain post-nuclear supernatant (PNS). Surface165 labelled plasma membrane (PM) microsomes were isolated by magnetic immunoaffinity using 
anti-FITC mAb-coated magnetic beads (Miltenyi Biotec) and concentrated by

167 ultracentrifugation in thickwall polycarbonate tubes (Beckman Coulter). PNS with the PM

168 fraction removed was likewise ultracentrifuged to sediment the "intracellular compartments"

169 (IC) fraction.

170

\section{Proteomic profiling of differentially expressed PM proteins}

172 Subcellular fractions (PM and IC) were prepared for mass spectrometry analysis from three 173 independent cell preparations using FASP protein digestion (Protein Discovery) as previously 174 described [36], with the following modifications. Proteins were reduced and digested with 175 sequence-grade modified Trypsin Gold (Promega). Peptides were eluted with ammonium

176 bicarbonate and acidified peptide mixtures from each biological replicate were analyzed in 177 technical triplicates by nanoflow reverse-phase liquid chromatography tandem mass 178 spectrometry (LC-MS/MS) on a nanoAcquity system (Waters) coupled to a Q-Exactive mass 179 spectrometer equipped with a nanoelectrospray ion source for automated MS/MS (Thermo 180 Fisher Scientific). High-resolution MS/MS spectra were processed with MaxQuant (version 181 1.6.7.0) for feature detection and protein identification using the Andromeda search engine 182 [37]. Extracted peak lists were searched against the UniProtKB/Swiss-Prot Mus musculus 183 database (Oct-2019) and a separate reverse decoy database to empirically assess the false 184 discovery rate (FDR) using a strict trypsin specificity allowing up to 2 missed cleavages. The 185 minimum required peptide length was 7 amino acids. The "match between runs" option in 186 MaxQuant was used [38]. PSM and protein identifications were filtered using a target-decoy approach at a FDR of 1\%. LFQ quantification was performed, with a minimum ratio of 2 .

188 Protein relative quantitative analysis was performed in R using MaxQuant's proteinGroups.txt 189 and LFQ intensities. Missing values were imputed using a random normal distribution of values 190 derived from the measured distribution of intensities [39] using a mean with a negative shift of

1911.8 standard deviations and a standard deviation equal to 0.3 of the standard deviation of the 192 measured intensities. The probability of differential expression was calculated using the 193 function lmFit from the Bioconductor package limma [40] followed by eBayes using the 194 default settings [41] and false-discovery rate correction using the Benjamini-Hochberg 195 method. The output included $\mathrm{P}$ value, confidence interval and ratio estimate. GO-term 196 enrichment analysis was performed using the enrichr function in the Bioconductor 197 clusterProfiler package [42]. Enrichment was calculated separately for the proteins 198 overrepresented in each fraction, relative to all proteins identified in collected fractions across 199 all the LCMS runs, and GO term association was filtered to include only experimental and high 
200 throughput evidence. Enrichment $\mathrm{P}$ values were corrected for multiple testing using the 201 function's 'fdr' method. The mass spectrometry proteomics data have been deposited to the 202 ProteomeXchange Consortium via the PRIDE [43]. The PRIDE database and related tools and 203 resources in 2019: improving support for quantification data. Nucleic Acids Res 47(D1):D442204 D450 partner repository with the dataset identifier PXD023115. 


\section{RESULTS}

\section{MARCH1, but not MARCH8, is functional in professional APC}

207 The first objective of this study was to establish which mouse cells express MARCH1 or 208 MARCH8. Their low level of transcription combined with fast turn-over contribute to maintain 209 the two proteins at non-detectable levels in primary cells, hampering definition of their 210 expression pattern. We reasoned that MHC II and/or CD86 could be used as reporters of 211 MARCH1 and MARCH8 activity because in all primary or transformed cells analyzed so far, 212 the surface level of these two receptors decreases by expression of either ligase [44]. Cells that 213 express MHC II or CD86 and either MARCH1 or MARCH8 should therefore display higher 214 levels of the receptor(s) in Marchf1 $^{-/-}$or Marchf8 $8^{-/-}$mice.

216 First, we examined professional APC (defined as cells that express detectable levels of MHC 217 II in the steady-state [45][46]) and T cells across various tissues. B cells, cDC1, cDC2, pDC 218 and macrophages from blood, spleen, subcutaneous lymph nodes (LN), thymus, peritoneal 219 cavity and lung of Marchf1 $^{-/-}$mice displayed elevated surface MHC II and CD86 relative to 220 WT cells, while no changes were observed in their Marchf $8^{-/-}$counterparts (Figure 1A-F). $221 \mathrm{CD}^{+}$and $\mathrm{CD}^{+} \mathrm{T}$ cells in spleen and LN showed no detectable surface MHC II and their CD86 222 expression [47] was not altered by MARCH1 - nor MARCH8-deficiency (Figure 1B-C). MHC 223 II and CD86 expression in peritoneal cDC deficient in both MARCH1 and MARCH8 $224\left(\right.$ Marchf1 $^{-/-} \times$Marchf8 $\left.^{-/-}\right)$was not elevated above that of Marchf1 ${ }^{-/}$cells (Supplementary 225 Figure 3). These results indicate that MARCH1 is expressed and active in all professional APC across various organs/tissues whereas MARCH8 is not or, if it is, does not display enough activity to compensate for the loss of MARCH1.

Next, we assessed the contribution of MARCH1 to activation-dependent regulation of MHC II and CD86 expression in $\mathrm{CDC}$, the archetypical professional APC. Toll-like receptor (TLR) ligands trigger an activation program in DC, known as DC maturation, that includes upregulation of MHC II and CD86 expression on the plasma membrane, among other receptors

233 [48]. Activation also leads to down-regulation of Marchf1 transcription which, combined with 234 fast turn-over of MARCH1, results in negligible expression of the protein in activated DCs $235[6][49][50][51]$. It has been assumed that this change is responsible for the accumulation of 236 MHC II and CD86 on the plasma membrane during cDC activation, but this has not been 237 directly examined. If ubiquitination were the dominant mechanism controlling how much 238 MHC II and CD86 is displayed on cDC, it would be expected that the expression of these two 
molecules would not vary during activation of March $^{-/-} \mathrm{cDC}$. However, activation of

240 Marchf1 $^{-/}$cDC further increased surface expression of MHC II by $\sim 1.5$ times, and increased

241 CD86 by $\sim 4$ times, when compared than their resting counterparts (Figure 2). CD40, which

242 also increases in expression during activation, though it is not a MARCH1 substrate, was

243 expressed at equivalent levels in WT and Marchf1 $^{-/} \mathrm{cDC}$ at both resting and activated states,

244 so up-regulation of MHC II and CD86 in Marchf1 $1^{-/} \mathrm{cDC}$ could not be attributed to overall

245 dysregulation of surface receptor expression (Figure 2). These results indicate that the main 246 contributor to MHC II and, especially, CD86 up-regulation during DC activation is not reduced

247 ubiquitination and degradation, but sustained deposition of newly synthesized molecules on

248 the cell surface [52][53]. DC lacking MARCH8 were indistinguishable from WT cDC in these

249 experiments, again indicating it has no role in resting or activated cDC (Figure 2).

\section{Granulocytes and monocytes express MHC II and CD86, but MARCH1 ubiquitination} maintains their surface expression at negligible levels

Next we assessed MARCH1 and MARCH8 activity in "atypical APC", this is, immune cells that are not considered professional APC but have been suggested to play antigen-presenting roles under certain conditions [46]. These include neutrophils, eosinophils and "inflammatory" $\left(\right.$ Ly6C $\mathrm{C}^{+}$) and "patrolling" (Ly6C') monocytes. While monocytes have the potential to develop into macrophages or DCs in inflamed sites [54], they are not thought to perform antigen presenting functions in their undifferentiated state [55]. We examined these atypical APC in spleen and lung. MHC II expression in WT neutrophils, eosinophils and monocytes was barely detectable by flow cytometry, staining at just above the background level observed in cells of mice that do not express any surface MHC II at all (Figure 3). Strikingly, all four cell types deficient in MARCH1 expressed MHC II at levels comparable to WT B cells or cDC (compare Figures 1B and $\mathbf{F}$ to Figures 3A and B, respectively), though expression was higher in spleen than it was in their lung counterparts (Figure 3A and B). CD86 was also highly expressed on all four MARCH1-deficient cell types, in this case both in spleen and lungs (Figure 3). MARCH8-deficient cells did not display altered MHC II or CD86 expression, confirming this member of the MARCH family is not expressed and/or active in hematopoietic cells (Figure 3). Of note, MARCH1-deficient T cells lacked surface MHC II and did not exhibit enriched CD86 expression when deficient in MARCH1 (Figure 1B), so neither mutation caused ectopic or increased expression of either molecule. We conclude that neutrophils, eosinophils, monocytes and possibly other atypical APC types [46] produce receptors for antigen presentation and $\mathrm{T}$ cell stimulation constitutively. While MARCH1 ubiquitination maintains 
273 the surface expression of these proteins at barely detectable levels, these atypical APC might

274 be capable of $\mathrm{CD}^{+} \mathrm{T}$ cell priming under certain conditions.

276 Previously predicted MARCH1 substrates display normal expression in $\mathrm{Marchf1}^{-/-}$mice

277 The second objective of this study was to identify which of the receptors found to be 278 ubiquitinated by MARCH1 or MARCH8 in (transfected) cell lines are also substrates in vivo under physiological conditions. Such receptors include CD44, CD71, CD95 and CD98 280 (reviewed in [5][56]). Carrying out this analysis also allowed us to address the possibility that, contrary to our conclusions above, MARCH8 might be expressed and active in these cells but dedicated to ubiquitinate these receptors rather than MHC II and CD86. This was not the case; expression of CD44, CD71, and CD98 was unaltered in Marchf8 ${ }^{-/-}$cDC and B cells compared

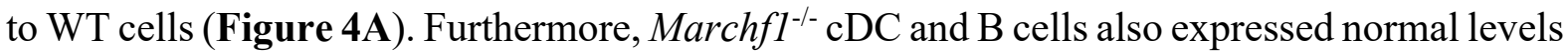
of the three receptors (Figure 4A). We extended our analysis to other regulatory receptors of $\mathrm{T}$ cell activation, including CD40 and members of the B7 family to which CD86 (B7.2) belongs: CD80 (B7.1), CD274 (PD-L1), CD273 (PD-L2), CD275 (ICOS-L), CD276 (B7-H3) and B7-H4. Expression of all these receptors on $\mathrm{cDC} 1, \mathrm{cDC} 2, \mathrm{pDC}$ and $\mathrm{B}$ cells was unaltered in the absence of MARCH1 (Figure 4B).

\section{Proteomic profiling of the plasma membrane of MARCH1- and MARCH8-deficient cDC} and $B$ cells

To more comprehensively address the role of MARCH1 and MARCH8 in APC membrane proteostasis, we performed an unbiased proteomic screen where we compared the proteomes of subcellular microsomal fractions enriched in plasma membrane (PM) of WT versus Marchf1 $^{-/-}$or Marchf8 ${ }^{-/} \mathrm{cDC}$ and B cells. We have previously shown this is a robust approach to identify differentially expressed PM proteins between closely related cell populations such as the two major $\mathrm{cDC}$ subtypes, $\mathrm{cDC} 1$ and $\mathrm{cDC} 2$ [57]. To obtain sufficient numbers of primary cDC for this purpose, these cells were expanded in WT, Marchf1 $1^{-/-}$and Marchf $8^{-/-}$mice bearing a melanoma cell line that secretes the DC growth factor, Flt3L [33]. The cDC expanded using this approach are phenotypically and functionally equivalent to their counterparts in untreated mice [57]. Splenic B cells were purified from untreated mice. The protein profiles of each fraction were identified by semi-quantitative mass spectrometry from three biological replicates, each measured in technical triplicates. 
We identified 1868-3108 proteins in the PM fraction of each cell type (Supplementary Table

307 1, total number of IDed proteins regardless of any restrictions). Of note, the subcellular 308 fractions are comprised of microsomes generated during mechanical homogenization of cells, 309 so their composition includes PM but also cytosolic and extracellular content 'trapped' inside 310 microsomes or tethered to the cell surface. This method enables analysis of proteins loosely 311 associated with the inner or outer leaflet of the PM. To test the efficiency of the PM-enrichment 312 method, we also sedimented and analyzed in parallel the compartments that remained in the 313 post-nuclear supernatant (PNS) of homogenized cells after retrieval of the PM fraction 314 (mitochondria, endosomes, etc, henceforth termed intracellular compartments, IC). We 315 identified 2073-3537 proteins in the IC fraction of each cell type (Supplementary Table 2, 316 total number of IDed proteins regardless of any restrictions). In order to assess enrichment of 317 the PM by this methodology, we compared Gene Ontology (GO) terms/annotations of the 318 proteins identified in the PM and IC fractions of each cell type. This comparison clearly 319 demonstrated enrichment of proteins known to be expressed at the cell surface in the PM 320 fractions, and enrichment of proteins known to occur in intracellular compartments in the IC 321 fractions, validating the subcellular fractionation protocol (Figure 5A and Supplementary 322 Figure 4).

324 Comparison of the PM proteomes of WT and Marchf1 ${ }^{-/} \mathrm{cDC}$ showed that, as expected, most 325 proteins were present at similar levels in the two preparations (1020 proteins in total, 326 Supplementary Table 3). Nine proteins were differentially expressed between WT and Marchf1 $^{-/}$cDC PM $\left[\log _{2}\right.$ protein ratio $>1$ or $<1$ and $-\log 10$ adjusted $p$ value $>3.47$ (5\% FDR)]

328 (Figure 5B and Supplementary Table 5). These included MHC II $\alpha$ and $\beta$ chains (H2-Aa and $329 \mathrm{H} 2-\mathrm{Ab} 1)$, as well as CD86, confirming the validity of our approach to detect MARCH1 330 substrates. Surprisingly, the protein that appeared most significantly overexpressed in the PM 331 of Marchf1 $^{-/}$cDC was complement component 3 (C3) (Figure 5B, Supplementary Table 5).

332 The remaining three proteins appearing over-expressed in the Marchf1/-/ $\mathrm{cDC}$ PM fraction are 333 not known to be immunoreceptors expressed at the PM: Cox7a2 is a mitochondrial protein,

334 Myadm a component of the cytoskeleton and MLV-related proviral Env polyprotein, a protein 335 endogenously encoded by a retrovirus integrated in the genome of commonly used mouse 336 strains [58]. As our main goal was to identify immunoregulatory MARCH1 substrates, we did 337 not investigate further whether these were true or artifactual "hits" of the proteomic analysis. 338 Comparison of the PM fractions of WT and Marchf8 $8^{-/-} \mathrm{cDC}$ did not reveal any differentially 
expressed proteins (Figure 5B, 922 proteins in total, Supplementary Table 3), supporting the previous results indicating that MARCH8 is not expressed/active in cDC.

342 Marchf1 $^{-/-}$and Marchf8 ${ }^{-/-}$B cells exhibited 45 and 40 enriched and 15 and 17 reduced proteins, 343 respectively, in their PM fractions $\left[\log _{2}\right.$ protein ratio $>1$ or $<1$. and $-\log 10$ adjusted $p$ value $344>2.5$ and $>2.36$ for $\operatorname{Marchf1}^{-/-}$and $\operatorname{Marchf}^{-/-}$, respectively (both 5\% FDR)] (Figure 5B, 345 Supplementary Table 6 and Supplementary Table 7, 1275 and 1819 proteins in total, 346 Supplementary Table 3). MHC II $\alpha$ and $\beta$ chains (H2-Aa and H2-Ab1), as well as CD86 and 347 C3 were the most significantly enriched proteins in the PM fraction of Marchf1 ${ }^{-/-} \mathrm{B}$ cells 348 (Figure 5B and Supplementary Table 6), but neither of the four were enriched in Marchf8-/349 B cells (Figure 5B and Supplementary Table 7). Only 14 of the 60 proteins differentially expressed in the PM fraction of Marchf1 ${ }^{-/-}$B cells, and 10 of the 57 proteins differentially expressed in the PM fraction of Marchf $^{-/-} \mathrm{B}$ cells, were immunoreceptors and/or proteins known to be expressed at the plasma membrane (Supplementary Table 6 and Supplementary Table 7). They included aminopeptidase N (CD13, gene Anpep), antigen-presenting glycoprotein CD1d, T cell differentiation antigen CD6 and the immunoglobulin epsilon Fc receptor CD23 (gene Fcer2). However, analysis by flow cytometry did not confirm differential expression in either Marchf1 ${ }^{-/-}$or Marchf8 ${ }^{-/-}$B cells (Supplementary Figure 5). The most likely explanation for detection of these "false positives" is that they were caused by subtle differences in the purity of the B cell preparations or their subcellular fractions. In conclusion, MHC class II and CD86 were the only membrane proteins that we could unequivocally confirm as MARCH1 substrates in B cells, and while we cannot discard the possibility that some of the "hits" found in the proteomic screen of Marchf8-/- B cells are indeed MARCH8 substrates, it is more likely that MARCH8 is not active in B cells, just as it is not in DC.

\section{MARCH8, not MARCH1, is active in non-hematopoietic cells}

365 The only cell type in which MARCH8 activity has been demonstrated is thymic epithelial cells (TEC), where it regulates MHC II surface expression but not CD86 [9][10]. Analysis of CD40, CD44, CD95 and CD98 expression in WT and Marchf8 ${ }^{-/-}$medullar and cortical TEC showed that neither of these receptors, which have been shown to be ubiquitinated in cell lines overexpressing MARCH8, are physiological substrates (Figure 6A).

Although TEC constitutively present antigens via MHC II, they are not hematopoietic cells, but of endodermal origin [59]. Therefore, we asked the question whether other cells 
373 ontogenically related to TEC also use MARCH8 to regulate surface MHC II expression. 374 Epithelial cells in the respiratory tract are known to express MHC II, with the highest level 375 found on type II alveolar epithelial cells (AEC) [60][61][62]. We found that MARCH8376 deficient type II AEC showed enriched MHC II surface expression (Figure 6B), but MHC II 377 levels in mutant endothelial cells, type I AEC and bronchial epithelial cells was not altered 378 (Figure 6B). Neither cell type displayed increased CD86 expression in the absence of 379 MARCH8, and lack of MARCH1 did not affect MHC II nor CD86 expression in any of the 380 cell types analyzed (Figure 6B). In conclusion, not all epithelial cells regulate MHC II 381 expression via ubiquitination, but those that do employ MARCH8. 
383 Determining which cells utilize MARCH1 and MARCH8 has been hampered by their low level 384 of expression, but analysis of MHC II and CD86 as surrogate markers of activity has allowed 385 us to establish the role of MARCH1 as a master regulator of MHC II and CD86 expression in 386 all hematopoietic cells. MARCH8 plays an equivalent role in the two major types of TEC and 387 in type II AEC, where it ubiquitinates MHC II. We did not observe high CD86 expression in

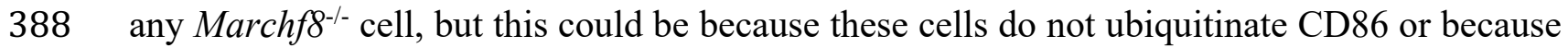
they do not express it. There are at least two precedents for ontogeny-specific differences in the use of components of MHC II antigen presentation machinery. Expression of CIITA, which directs transcription of the genes for MHC II and for several accessory molecules involved in antigen presentation, is driven by distinct promoters in hematopoietic and non-hematopoietic cells [63]. Proteolysis of the chaperone invariant chain, a critical step in the MHC II antigen presentation pathway, is carried out by cathepsin $\mathrm{S}$ in hematopoietic cells and by and cathepsin $\mathrm{L}$ in non-hematopoietic cells [64]. It is unclear why this dichotomy exists, which is probably caused by the establishment of cell lineage-specific gene programs during embryonic development.

While our finding that MARCH1 is operative in professional APC confirmed previous observations, we were surprised to observe high MHC II and CD86 expression in nonprofessional APC lacking MARCH1. This was not caused by ectopic induction or overexpression of either molecule because MARCH1-deficient T cells maintained WT levels of MHC II (negative) and CD86 (low) expression. As MARCH1 ubiquitinates substrates that have already trafficked through the cell surface, this finding implies that atypical APC express and deposit on their plasma membrane larger amounts of MHC II and CD86 than is usually appreciated, but their steady-state levels are kept low by virtue of MARCH1 ubiquitination and accelerated turn-over. Eosinophils are associated with inflammatory responses during allergy or parasitic infections, while neutrophils are recruited in abundant numbers to sites of tissue damage or infection. The role of MHC II antigen presentation by either cell type is controversial. While there is evidence for both purified eosinophils and neutrophils that

411 demonstrates their capacity to present antigen via MHC II [46], it is difficult to exclude the 412 possibility of DC contamination in these assays. In vivo evidence of their antigen presentation 413 capacity is scarce but there are reported examples where both eosinophils [65] and neutrophils $414[66][67][68]$ contribute to enhancing antigen-specific $\mathrm{CD}^{+} \mathrm{T}$ cell responses. The realization 
415 that these cells regulate MHC II and CD86 via ubiquitination utilizing the same mechanism as

416 professional APC lends weight to the notion that they perform antigen presentation in vivo.

418 One of the functions attributed to MARCH8 in humans is to ubiquitinate viral proteins

419 deposited on the plasma membrane of infected cells and that will be incorporated in the envelop 420 of the virion upon budding [69][70][71]. The reduction of viral protein expression that ensues 421 inhibits spread of the infection, protecting the host. This activity has not been described in 422 mice, but our results suggest that if it occurs in this species, it is unlikely to be operative in 423 hematopoietic cells, where perhaps other members of the MARCH family replace the function 424 of MARCH8.

425

426 While several substrates have been identified for MARCH1 and MARCH8 based on studies 427 using overexpression and/or cell lines, our flow cytometry analysis rules out CD44, CD71, 428 CD95 and CD98 as bona fide MARCH1 or MARCH8 substrates in all primary cells examined. 429 This highlights that caution needs to be taken when interpreting studies that rely on E3 Ub 430 ligase overexpression. Our unbiased proteomic profiling of B cells and DC unequivocally 431 confirmed the role of MARCH1 in MHC II and CD86 ubiquitination in both cell types, but did 432 not reveal any other MARCH1 substrate that we could validate by flow cytometry with the 433 exception of complement C3. Further investigations will be required to determine if enriched 434 levels of surface $\mathrm{C} 3$ in these cells is a direct or indirect effect of MACRH1 deficiency, as we 435 have also shown that high MHC II expression in Marchf1 ${ }^{-/}$cells indirectly induces higher or 436 lower expression of other surface receptors that are not direct MARCH1 substrates [72]. 437 However, the magnitude of these changes is below the level of resolution afforded by high438 throughput, unbiased proteomic analysis of subcellular fractions. We did not observe changes 439 in expression of any protein on the plasma membrane of Marchf8/- DC. The "hits" detected 440 Marchf $^{-/-}$B cell membrane could be attributed to contamination with other subcellular 441 compartments because they were not classified as plasma membrane proteins and/or could not 442 be validated as differentially expressed by flow cytometry. The proteomic analysis thus 443 confirmed that neither B cells nor DC express functional MARCH8.

444

445 In summary, MHC II is the only membrane protein unequivocally regulated by MARCH1 and 446 MARCH8 in primary mouse cells, with each ligase playing its role in haemopoietic and non447 haemopoietic cells, respectively. CD86 is also a MARCH1 substrate in hematopoietic cells. 
448 These results help to predict the potential effects of genetic or pharmacological manipulation

449 of MARCH1 or MARCH8 activities as a treatment for immunological disorders.

450

451

452

\section{ACKNOWLEDGEMENTS}

We thank the Antibody Services Facility and Genomics Hub (Walter and Eliza Hall Institute)

453 and the Melbourne Cytometry Platform (The University of Melbourne) for expert assistance.

454 JAV: NHMRC Fellowship 1058193 and 1154502, NHMRC Program 1016629 and 1113293,

455 ARC DP160103134 and DP110101383, and Human Frontiers Science Program Grant 456 0064/2011.

457 PS: Australian Research Training Programme Scholarship provided by the Australian 458 Commonwealth Government and the University of Melbourne. 


\section{REFERENCES}

460 [1] D. Komander and M. Rape, "The Ubiquitin Code," Annu. Rev. Biochem., vol. 81, no.

461

462 1, pp. 203-229, Jul. 2012, doi: 10.1146/annurev-biochem-060310-170328.

463

464

465

466

467

468

469

470

471

472

473

474

475

476

477

478

479

480

[2] H. Liu, J. D. Mintern, and J. A. Villadangos, "MARCH ligases in immunity," Curr. Opin. Immunol., vol. 58, no. Box 1, pp. 38-43, Jun. 2019, doi:

10.1016/j.coi.2019.03.001.

[3] L. Coscoy, D. J. Sanchez, and D. Ganem, "A novel class of herpesvirus-encoded membrane-bound E3 ubiquitin ligases regulates endocytosis of proteins involved in immune recognition," J. Cell Biol., vol. 155, no. 7, pp. 1265-1274, Dec. 2001, doi: 10.1083/jcb.200111010.

[4] S. Ishido, C. Wang, B.-S. Lee, G. B. Cohen, and J. U. Jung, "Downregulation of Major Histocompatibility Complex Class I Molecules by Kaposi's Sarcoma-Associated Herpesvirus K3 and K5 Proteins," J. Virol., vol. 74, no. 11, pp. 5300-5309, Jun. 2000, doi: 10.1128/JVI.74.11.5300-5309.2000.

[5] T. Samji, S. Hong, and R. E. Means, "The Membrane Associated RING-CH Proteins: A Family of E3 Ligases with Diverse Roles through the Cell," Int. Sch. Res. Not., vol. 2014, pp. 1-23, 2014, doi: 10.1155/2014/637295.

[6] L. J. Young et al., "Differential MHC class II synthesis and ubiquitination confers distinct antigen-presenting properties on conventional and plasmacytoid dendritic cells," Nat. Immunol., vol. 9, no. 11, pp. 1244-1252, Nov. 2008, doi: 10.1038/ni.1665.

[7] K.-J. Cho, E. Walseng, S. Ishido, and P. A. Roche, "Ubiquitination by March-I prevents MHC class II recycling and promotes MHC class II turnover in antigen-

481

482

483

484

485

486

487

488

489

490

491

492

493

494

495

496

497 presenting cells," Proc. Natl. Acad. Sci., vol. 112, no. 33, pp. 10449-10454, Aug. 2015, doi: 10.1073/pnas.1507981112.

[8] O. Bannard et al., "Ubiquitin-mediated fluctuations in MHC class II facilitate efficient germinal center B cell responses," J. Exp. Med., vol. 213, no. 6, pp. 993-1009, May 2016, doi: 10.1084/jem.20151682.

[9] H. Liu et al., "Ubiquitin ligase MARCH 8 cooperates with CD83 to control surface MHC II expression in thymic epithelium and CD4 T cell selection," J. Exp. Med., vol. 213, no. 9, pp. 1695-1703, Aug. 2016, doi: 10.1084/jem.20160312.

[10] J. von Rohrscheidt et al., "Thymic CD4 T cell selection requires attenuation of March8-mediated MHCII turnover in cortical epithelial cells through CD83," J. Exp. Med., vol. 213, no. 9, pp. 1685-1694, Aug. 2016, doi: 10.1084/jem.20160316.

[11] J. Oh et al., "MARCH1-mediated MHCII ubiquitination promotes dendritic cell selection of natural regulatory T cells," J. Exp. Med., vol. 210, no. 6, pp. 1069-1077, Jun. 2013, doi: 10.1084/jem.20122695.

[12] R. Ishikawa, M. Kajikawa, and S. Ishido, "Loss of MHC II ubiquitination inhibits the activation and differentiation of CD4 T cells," Int. Immunol., vol. 26, no. 5, pp. 283289, May 2014, doi: 10.1093/intimm/dxt066.

498

499

[13] T. Galbas et al., "MARCH1 E3 Ubiquitin Ligase Dampens the Innate Inflammatory Response by Modulating Monocyte Functions in Mice," J. Immunol., vol. 198, no. 2 , pp. 852-861, Jan. 2017, doi: 10.4049/jimmunol.1601168.

500

501

502

503

504

505

[14] J. Wu et al., "The E3 ubiquitin ligase MARCH1 regulates antimalaria immunity through interferon signaling and T cell activation," Proc. Natl. Acad. Sci. U. S. A., vol. 117, no. 28, pp. 16567-16578, 2020, doi: 10.1073/pnas.2004332117.

[15] Y. Zhang et al., "Membrane-associated RING-CH (MARCH) 1 and 2 are MARCH family members that inhibit HIV-1 infection," J. Biol. Chem., vol. 294, no. 10, pp. 3397-3405, Mar. 2019, doi: 10.1074/jbc.AC118.005907.

[16] L. Xie et al., "MARCH1 encourages tumour progression of hepatocellular carcinoma via regulation of PI3K-AKT- $\beta$-catenin pathways," J. Cell. Mol. Med., vol. 23, no. 5, 
pp. 3386-3401, 2019, doi: 10.1111/jcmm.14235.

[17] O. A. Kishta et al., "March1 E3 Ubiquitin Ligase Modulates Features of Allergic Asthma in an Ovalbumin-Induced Mouse Model of Lung Inflammation," J. Immunol. Res., vol. 2018, pp. 1-17, 2018, doi: 10.1155/2018/3823910.

[18] M. Toyomoto, S. Ishido, N. Miyasaka, H. Sugimoto, and H. Kohsaka, “Anti-arthritic effect of E3 ubiquitin ligase, c-MIR, expression in the joints," Int. Immunol., vol. 23, no. 3, pp. 177-183, Mar. 2011, doi: 10.1093/intimm/dxq470.

[19] C. A. Eyster, N. B. Cole, S. Petersen, K. Viswanathan, K. Früh, and J. G. Donaldson, "MARCH ubiquitin ligases alter the itinerary of clathrin-independent cargo from recycling to degradation," Mol. Biol. Cell, vol. 22, no. 17, pp. 3218-3230, Sep. 2011, doi: 10.1091/mbc.e10-11-0874.

[20] H. Fujita, Y. Iwabu, K. Tokunaga, and Y. Tanaka, "Membrane-associated RING-CH (MARCH) 8 mediates the ubiquitination and lysosomal degradation of the transferrin receptor," J. Cell Sci., vol. 126, no. 13, pp. 2798-2809, 2013, doi: 10.1242/jcs.119909.

[21] K. Corcoran, M. Jabbour, C. Bhagwandin, M. J. Deymier, D. L. Theisen, and L. Lybarger, "Ubiquitin-mediated Regulation of CD86 Protein Expression by the Ubiquitin Ligase Membrane-associated RING-CH-1 (MARCH1)," J. Biol. Chem., vol. 286, no. 43, pp. 37168-37180, Oct. 2011, doi: 10.1074/jbc.M110.204040.

[22] E. Bartee et al., "Downregulation of Major Histocompatibility Complex Class I by Human Ubiquitin Ligases Related to Viral Immune Evasion Proteins Downregulation of Major Histocompatibility Complex Class I by Human Ubiquitin Ligases Related to Viral Immune Evasion Proteins," J. Virol., vol. 78, no. 3, pp. 1109-1120, 2004, doi: 10.1128/JVI.78.3.1109.

[23] E. Bartee, A. McCormack, and K. Früh, "Quantitative membrane proteomics reveals new cellular targets of viral immune modulators," PLoS Pathog., vol. 2, no. 10, pp. 0975-0988, 2006, doi: 10.1371/journal.ppat.0020107.

[24] M. Jabbour, E. M. Campbell, H. Fares, and L. Lybarger, "Discrete Domains of MARCH1 Mediate Its Localization, Functional Interactions, and Posttranscriptional Control of Expression," J. Immunol., vol. 183, no. 10, pp. 6500-6512, Nov. 2009, doi: 10.4049/jimmunol.0901521.

[25] S. Kaul, S. K. Mittal, and P. A. Roche, "A major isoform of the E3 ubiquitin ligase March-I in antigen-presenting cells has regulatory sequences within its gene," J. Biol. Chem., vol. 293, no. 12, pp. 4478-4485, Mar. 2018, doi: 10.1074/jbc.RA118.001775.

[26] J. Thibodeau et al., "Interleukin-10-induced MARCH1 mediates intracellular sequestration of MHC class II in monocytes," Eur. J. Immunol., vol. 38, no. 5, pp. 1225-1230, May 2008, doi: 10.1002/eji.200737902.

[27] B. Zhao et al., "Protein engineering in the ubiquitin system: Tools for discovery and beyond," Pharmacol. Rev., vol. 72, no. 2, pp. 380-413, 2020, doi: 10.1124/pr.118.015651.

[28] M. J. Edelmann, B. Nicholson, and B. M. Kessler, "Pharmacological targets in the ubiquitin system offer new ways of treating cancer, neurodegenerative disorders and infectious diseases.," Expert Rev. Mol. Med., vol. 13, no. November, pp. 1-17, 2011, doi: $10.1017 / \mathrm{s} 1462399411002031$.

[29] M.-C. Bourgeois-Daigneault and J. Thibodeau, "Autoregulation of MARCH1 Expression by Dimerization and Autoubiquitination," J. Immunol., vol. 188, no. 10, pp. 4959-4970, May 2012, doi: 10.4049/jimmunol.1102708.

[30] L. Lei, J. Bandola-Simon, and P. A. Roche, "Ubiquitin-conjugating enzyme E2 D1 (Ube2D1) mediates lysine-independent ubiquitination of the E3 ubiquitin ligase March-I," J. Biol. Chem., vol. 293, no. 11, pp. 3904-3912, Mar. 2018, doi: 10.1074/jbc.RA117.001322. 
559

560

561

562

563

564

565

566

567

568

569

570

571

572

573

574

575

576

577

578

579

580

581

582

583

584

585

586

587

588

589

590

591

592

593

594

595

596

597

598

599

600

601

602

603

604

605

606

607

608

[31] Y. Matsuki et al., "Novel regulation of MHC class II function in B cells," EMBO J., vol. 26, no. 3, pp. 846-854, Feb. 2007, doi: 10.1038/sj.emboj.7601556.

[32] F. Köntgen, G. Süss, C. Stewart, M. Steinmetz, and H. Bluethmann, "Targeted disruption of the MHC class II Aa gene in C57BL/6 mice.," Int. Immunol., vol. 5, no. 8, pp. 957-64, Aug. 1993, doi: 10.1093/intimm/5.8.957.

[33] N. Mach, S. Gillessen, S. B. Wilson, C. Sheehan, M. Mihm, and G. Dranoff, "Differences in dendritic cells stimulated in vivo by tumors engineered to secrete granulocyte-macrophage colony-stimulating factor or Flt3-ligand.," Cancer Res., vol. 60, no. 12, pp. 3239-46, Jun. 2000.

[34] D. Vremec, "The Isolation of Mouse Dendritic Cells from Lymphoid Tissues and the Identification of Dendritic Cell Subtypes by Multiparameter Flow Cytometry," in Methods in molecular biology (Clifton, N.J.), vol. 595, no. 11-12, 2010, pp. 205-229.

[35] E. Segura, A. L. Albiston, I. P. Wicks, S. Y. Chai, and J. A. Villadangos, "Different cross-presentation pathways in steady-state and inflammatory dendritic cells," Proc. Natl. Acad. Sci. U. S. A., vol. 106, no. 48, pp. 20377-20381, 2009, doi: 10.1073/pnas.0910295106.

[36] J. R. Wiśniewski, A. Zougman, N. Nagaraj, and M. Mann, "Universal sample preparation method for proteome analysis," Nat. Methods, vol. 6, no. 5, pp. 359-362, May 2009, doi: 10.1038/nmeth.1322.

[37] J. Cox, N. Neuhauser, A. Michalski, R. A. Scheltema, J. V. Olsen, and M. Mann, "Andromeda: A peptide search engine integrated into the MaxQuant environment," $J$. Proteome Res., vol. 10, no. 4, pp. 1794-1805, 2011, doi: 10.1021/pr101065j.

[38] J. Cox and M. Mann, "MaxQuant enables high peptide identification rates, individualized p.p.b.-range mass accuracies and proteome-wide protein quantification," Nat. Biotechnol., vol. 26, no. 12, pp. 1367-1372, 2008, doi: $10.1038 /$ nbt.1511.

[39] J. Cox, M. Y. Hein, C. A. Luber, I. Paron, N. Nagaraj, and M. Mann, "Accurate proteome-wide label-free quantification by delayed normalization and maximal peptide ratio extraction, termed MaxLFQ," Mol. Cell. Proteomics, vol. 13, no. 9, pp. 2513-2526, 2014, doi: 10.1074/mcp.M113.031591.

[40] M. E. Ritchie et al., "Limma powers differential expression analyses for RNAsequencing and microarray studies," Nucleic Acids Res., vol. 43, no. 7, p. e47, 2015, doi: $10.1093 / \mathrm{nar} / \mathrm{gkv} 007$.

[41] B. Phipson, S. Lee, I. J. Majewski, W. S. Alexander, and G. K. Smyth, "Robust hyperparameter estimation protects against hypervariable genes and improves power to detect differential expression," Ann. Appl. Stat., vol. 10, no. 2, pp. 946-963, Jun. 2016, doi: 10.1214/16-AOAS920.

[42] G. Yu, L. G. Wang, Y. Han, and Q. Y. He, "ClusterProfiler: An R package for comparing biological themes among gene clusters," Omi. A J. Integr. Biol., vol. 16, no. 5, pp. 284-287, 2012, doi: 10.1089/omi.2011.0118.

[43] Y. Perez-Riverol et al., "The PRIDE database and related tools and resources in 2019: Improving support for quantification data," Nucleic Acids Res., vol. 47, no. D1, pp. D442-D450, 2019, doi: 10.1093/nar/gky1106.

[44] M. Ohmura-Hoshino et al., "Inhibition of MHC class II expression and immune responses by c-MIR.," J. Immunol., vol. 177, no. 1, pp. 341-54, Jul. 2006, doi: 10.4049/jimmunol.177.1.341.

[45] O. Lassila, O. Vainio, and P. Matzinger, "Can B cells turn on virgin T cells?," Nature, vol. 334, no. 6179, pp. 253-255, 1988, doi: 10.1038/334253a0.

[46] T. Kambayashi and T. M. Laufer, "Atypical MHC class II-expressing antigenpresenting cells: can anything replace a dendritic cell?," Nat. Rev. Immunol., vol. 14, 
614

615

616

617

618

619

620

621

622

623

624

625

626

627

628

629

630

631

632

633

634

635

636

637

638

639

640

641

642

643

644

645

646

647

648

649

650

651

652

653

654

655

656

657

658

no. 11 , pp. $719-730$, Nov. 2014, doi: 10.1038/nri3754.

[47] J. Eberlein, B. Davenport, T. T. Nguyen, F. Victorino, T. Sparwasser, and D. Homann, "Multiple Layers of CD80/86-Dependent Costimulatory Activity Regulate Primary, Memory, and Secondary Lymphocytic Choriomeningitis Virus-Specific T Cell Immunity," J. Virol., vol. 86, no. 4, pp. 1955-1970, 2012, doi: 10.1128/jvi.05949-11.

[48] R. Spörri and C. Reis e Sousa, "Inflammatory mediators are insufficient for full dendritic cell activation and promote expansion of CD4+ T cell populations lacking helper function," Nat. Immunol., vol. 6, no. 2, pp. 163-170, 2005, doi: 10.1038/ni1162.

[49] J. Vega-Ramos, A. Roquilly, Y. Zhan, L. J. Young, J. D. Mintern, and J. A. Villadangos, "Inflammation Conditions Mature Dendritic Cells To Retain the Capacity To Present New Antigens but with Altered Cytokine Secretion Function," J. Immunol., vol. 193, no. 8, pp. 3851-3859, 2014, doi: 10.4049/jimmunol.1303215.

[50] A. De Gassart et al., "MHC class II stabilization at the surface of human dendritic cells is the result of maturation-dependent MARCH I down-regulation," Proc. Natl. Acad. Sci., vol. 105, no. 9, pp. 3491-3496, Mar. 2008, doi: 10.1073/pnas.0708874105.

[51] T. Galbas and J. Thibodeau, "Cell-type specific regulation of MARCH1 E3 ubiquitin ligase by the anti-inflammatory cytokine IL-10," Open J. Immunol., vol. 02, no. 04, pp. 161-167, 2012, doi: 10.4236/oji.2012.24020.

[52] J. A. Villadangos et al., "MHC Class II Expression Is Regulated in Dendritic Cells Independently of Invariant Chain Degradation," Immunity, vol. 14, no. 6, pp. 739-749, Jun. 2001, doi: 10.1016/S1074-7613(01)00148-0.

[53] N. S. Wilson, D. El-Sukkari, and J. A. Villadangos, "Dendritic cells constitutively present self antigens in their immature state in vivo and regulate antigen presentation by controlling the rates of MHC class II synthesis and endocytosis," Blood, vol. 103, no. 6, pp. 2187-2195, Mar. 2004, doi: 10.1182/blood-2003-08-2729.

[54] C. Auffray, M. H. Sieweke, and F. Geissmann, "Blood Monocytes: Development, Heterogeneity, and Relationship with Dendritic Cells," Annu. Rev. Immunol., vol. 27, no. 1, pp. 669-692, 2009, doi: 10.1146/annurev.immunol.021908.132557.

[55] C. V. Jakubzick, G. J. Randolph, and P. M. Henson, "Monocyte differentiation and antigen-presenting functions," Nat. Rev. Immunol., vol. 17, no. 6, pp. 349-362, Jun. 2017, doi: 10.1038/nri.2017.28.

[56] J. Bauer, O. Bakke, and J. P. Morth, "Overview of the membrane-associated RINGCH (MARCH) E3 ligase family," N. Biotechnol., vol. 38, pp. 7-15, Sep. 2017, doi: 10.1016/j.nbt.2016.12.002.

[57] E. Segura et al., "Differential expression of pathogen-recognition molecules between dendritic cell subsets revealed by plasma membrane proteomic analysis," Mol. Immunol., vol. 47, no. 9, pp. 1765-1773, May 2010, doi: 10.1016/j.molimm.2010.02.028.

[58] C. Stocking and C. A. Kozak, "Endogenous retroviruses," Cell. Mol. Life Sci., vol. 65, no. 21, pp. 3383-3398, Nov. 2008, doi: 10.1007/s00018-008-8497-0.

[59] J. Gordon et al., "Functional evidence for a single endodermal origin for the thymic epithelium," Nat. Immunol., vol. 5, no. 5, pp. 546-553, 2004, doi: 10.1038/ni1064.

[60] J. E. Wosen, D. Mukhopadhyay, C. Macaubas, and E. D. Mellins, "Epithelial MHC Class II Expression and Its Role in Antigen Presentation in the Gastrointestinal and Respiratory Tracts," Front. Immunol., vol. 9, no. SEP, pp. 1-14, Sep. 2018, doi: 10.3389/fimmu.2018.02144.

[61] H. Nakano, K. Nakano, and D. N. Cook, "Isolation and Purification of Epithelial and Endothelial Cells from Mouse Lung," in Methods in Molecular Biology, vol. 1799, R.

L. Reinhardt, Ed. New York, NY: Springer New York, 2018, pp. 59-69.

[62] K. Hasegawa et al., "Fraction of MHCII and EpCAM expression characterizes distal 
661

662

663

664

665

666

667

668

669

670

671

672

673

674

675

676

677

678

679

680

681

682

683

684

685

686

687

688

689

690

691

692

693

694

695

696

697

698

699

700

701

702

703

704

705

706

lung epithelial cells for alveolar type 2 cell isolation," Respir. Res., vol. 18, no. 1, p. 150, Dec. 2017, doi: 10.1186/s12931-017-0635-5.

[63] W. Reith and B. Mach, "The Bare Lymphocyte Syndrome and the Regulation of MHC Expression," Annu. Rev. Immunol., vol. 19, no. 1, pp. 331-373, Apr. 2001, doi: 10.1146/annurev.immunol.19.1.331.

[64] J. A. Villadangos and H. L. Ploegh, "Proteolysis in MHC class II antigen presentation: Who's in charge?," Immunity, vol. 12, no. 3, pp. 233-239, 2000, doi: 10.1016/S10747613(00)80176-4.

[65] U. M. Padigel, J. J. Lee, T. J. Nolan, G. A. Schad, and D. Abraham, "Eosinophils Can Function as Antigen-Presenting Cells To Induce Primary and Secondary Immune Responses to Strongyloides stercoralis," Infect. Immun., vol. 74, no. 6, pp. 3232-3238, Jun. 2006, doi: 10.1128/IAI.02067-05.

[66] D. S. Abi Abdallah, C. E. Egan, B. A. Butcher, and E. Y. Denkers, "Mouse neutrophils are professional antigen-presenting cells programmed to instruct Th1 and Th17 T-cell differentiation," Int. Immunol., vol. 23, no. 5, pp. 317-326, May 2011, doi: 10.1093/intimm/dxr007.

[67] M. Vono, A. Lin, A. Norrby-Teglund, R. A. Koup, F. Liang, and K. Loré, "Neutrophils acquire the capacity for antigen presentation to memory CD4+ T cells in vitro and ex vivo," Blood, vol. 129, no. 14, pp. 1991-2001, Apr. 2017, doi: 10.1182/blood-2016-10-744441.

[68] A. Lin and K. Loré, "Granulocytes: New Members of the Antigen-Presenting Cell Family," Front. Immunol., vol. 8, no. DEC, pp. 1-8, Dec. 2017, doi: 10.3389/fimmu.2017.01781.

[69] T. Tada et al., "MARCH8 inhibits HIV-1 infection by reducing virion incorporation of envelope glycoproteins," Nat. Med., vol. 21, no. 12, pp. 1502-1507, Dec. 2015, doi: 10.1038/nm.3956.

[70] Y. Zhang, T. Tada, S. Ozono, S. Kishigami, H. Fujita, and K. Tokunaga, "MARCH8 inhibits viral infection by two different mechanisms," Elife, vol. 9, pp. 1-14, Aug. 2020, doi: 10.7554/eLife.57763.

[71] S. Kumar et al., "MARCH8 Ubiquitinates the Hepatitis C Virus Nonstructural 2 Protein and Mediates Viral Envelopment," Cell Rep., vol. 26, no. 7, pp. 1800-1814.e5, 2019, doi: 10.1016/j.celrep.2019.01.075.

[72] K. R. Wilson et al., "MARCH1-mediated ubiquitination of MHC II impacts the MHC I antigen presentation pathway," PLoS One, vol. 13, no. 7, p. e0200540, Jul. 2018, doi: 10.1371/journal.pone.0200540.

[73] S. E. Liyanage et al., "Flow cytometric analysis of inflammatory and resident myeloid populations in mouse ocular inflammatory models.," Exp. Eye Res., vol. 151, pp. 16070, 2016, doi: 10.1016/j.exer.2016.08.007.

[74] L. Ardouin et al., "Broad and Largely Concordant Molecular Changes Characterize Tolerogenic and Immunogenic Dendritic Cell Maturation in Thymus and Periphery," Immunity, vol. 45, no. 2, pp. 305-318, Aug. 2016, doi: 10.1016/j.immuni.2016.07.019.

[75] C. C. Bain et al., "Long-lived self-renewing bone marrow-derived macrophages displace embryo-derived cells to inhabit adult serous cavities," Nat. Commun., vol. 7, no. 1 , p. ncomms 11852, Sep. 2016, doi: 10.1038/ncomms11852.

[76] F. R. Svedberg et al., "The lung environment controls alveolar macrophage metabolism and responsiveness in type 2 inflammation," Nat. Immunol., vol. 20, no. 5, pp. 571-580, 2019, doi: 10.1038/s41590-019-0352-y. 
710 haemopoietic professional antigen presenting cells. Surface expression of MHC II and

711 CD86 in (A) blood B cells, (B) splenic cDC1, cDC2, pDC, B cells, macrophages (MAC) and $712 \mathrm{CD}^{+} / \mathrm{CD}^{+} \mathrm{T}$ cells, (C) resident and migratory $\mathrm{cDC} 1$ and $\mathrm{cDC} 2$ as well as $\mathrm{B}$ cells, 713 macrophages and $\mathrm{CD}^{+} / \mathrm{CD}^{+} \mathrm{T}$ cells in subcutaneous (axillary + inguinal) lymph nodes, (D) 714 thymic cDC1, cDC2 and B cells, (D) peritoneal cDC1, cDC2, B cells and small/large 715 macrophages and (E) lung $\mathrm{cDC} 1, \mathrm{cDC} 2, \mathrm{pDC}, \mathrm{B}$ cells and alveolar/interstitial macrophages, 716 all purified from WT mice or mice deficient in either MARCH1 or MARCH8. In all cases a 717 fluorescence-minus-one (FMO) control was included, for which cells were incubated with the 718 corresponding multi-colour staining panel, excluding the fluorescently labelled antibody 719 species of interest (i.e. anti-CD86 or anti-MHC II mAb). Bars represent mean \pm SD with each 720 symbol representing an individual mouse $(n=4-5)$. Statistical analysis was performed using one-way ANOVA followed by Sidak's multiple comparisons test. $* * * * p<0.0001$, *** $\mathrm{p}<$ $0.0002, * * \mathrm{p}<0.002, * \mathrm{p}<0.03$, n.s. not significant. in DC maturation. (A) Surface expression of MHC II and CD86 in CpG-activated cDC purified from the spleen of WT mice or mice deficient in either MARCH1 or MARCH8. Purified splenic cDC ( $2 \times 10^{5}$ cells) were incubated for 16 hours ex vivo with or without $50 \mathrm{~nm}$ CpG in 96-well plates, then washed and analyzed by flow cytometry for MHC II and CD86 surface expression. A fluorescence-minus-one (FMO) control was included, for which cells were incubated with the corresponding multi-colour staining panel, excluding the fluorescently labelled antibody species of interest (i.e. anti-CD86 or anti-MHC II mAb). Bars represent mean \pm SD with each symbol representing an individual mouse $(n=6)$. Statistical analysis was performed using one-way ANOVA followed by Sidak's multiple comparisons test. ${ }^{* * * *} \mathrm{p}<$ $0.0001, * * * \mathrm{p}<0.0002,{ }^{* *} \mathrm{p}<0.002, * \mathrm{p}<0.03$, n.s. not significant. eosinophils and inflammatory and patrolling monocytes purified from (A) spleen and (B) lung of WT mice or mice deficient in I-A $\alpha$, MARCH1 or MARCH8. Bars represent mean \pm SD with each symbol representing an individual mouse $(n=5)$. Statistical analysis was performed using 
one-way ANOVA followed by Sidak's multiple comparisons test. $* * * * \mathrm{p}<0.0001, * * * \mathrm{p}<$

$7420.0002, * * \mathrm{p}<0.002,{ }^{*} \mathrm{p}<0.03$, n.s. not significant.

744 Figure 4. Analysis of putative MARCH1 and MARCH8 substrates in haemopoietic 745 antigen presenting cells. (A) Surface expression of MHC II, CD86, CD80, CD40, CD44, 746 CD71 and CD98 in splenic B cells, cDC1 and cDC2 from WT, Marchf1 ${ }^{-/-}$and Marchf8 $8^{-/}$mice.

747 (B) Surface expression of B7 costimulatory molecules, PD-L1, PD-L2, ICOS-L, B7-H3 and 748 B7-H4, in splenic cDC1, cDC2, pDC and B cells purified from WT or Marchf1 $1^{-/-}$mice. In all 749 cases a fluorescence-minus-one (FMO) control was included, for which cells were incubated 750 with the corresponding multi-colour staining panel, excluding the fluorescently labelled 751 antibody species of interest. Bars represent mean \pm SD with each symbol representing an 752 individual mouse ( $\mathrm{n}=3-6)$. Statistical analysis was performed using one-way ANOVA followed 753 by Sidak's multiple comparisons test. $* * * * p<0.0001, * * * \mathrm{p}<0.0002, * * \mathrm{p}<0.002, * \mathrm{p}<$ $754 \quad 0.03$, n.s. not significant.

755

Figure 5. Proteomic analysis of differentially expressed proteins in the plasma membrane fraction between WT and $\mathrm{Marchf1}^{-/-}$or $\mathrm{Marchf8}^{-/-} \mathrm{CDC}$ and B cells. Proteomic analysis of plasma membrane (PM)-enriched microsome fractions of splenic cDC and B cells purified from WT, Marchf1 ${ }^{-/}$or Marchf8-/- mice. PM fractions were purified from post-nuclear supernatants of $\mathrm{mAb}$ surface stained $\mathrm{cDC}$ and $\mathrm{B}$ cells via magnetic immunoaffinity and analysed by semi-quantitative mass spectrometry from three biological replicates (in total $3 \times 8$ samples; WT vs. Marchf1 $^{-/-}$and WT vs. Marchf8 $8^{-/-} \mathrm{cDC}+\mathrm{WT}$ vs. Marchf1 $^{-/-}$and WT vs. Marchf8-/- B cells). The remaining compartments (mitochondria, endosomes, etc.) from the post-nuclear supernatant of homogenized cells following PM fraction retrieval was termed intracellular compartment (IC). (A) Enrichment analysis (performed using the function enricher included in the Bioconductor clusterProfiler package [42]) of detected proteins via MS from PM or IC fractions from cDC and B cells of WT versus Marchf1 ${ }^{-/-}$and WT versus $\operatorname{Marchf}^{-/-}$mice. Annotated GO-IDs for detected proteins were grouped into categories of 'Cell surface', 'Intracellular Compartment (IC)' and 'others' based on experimentally verified Gene Ontology (GO) annotations. 'Cell surface' category included the GO terms 'plasma membrane', 'external side of plasma membrane' and 'cell surface' among others, while the categories 'Intracellular Compartment (IC)' and 'others' included GO terms such as

773 'mitochondrial membrane' and 'endoplasmic reticulum' as well as 'myelin sheath', respectively. For a detailed list of all annotated GO terms of all fractions please see 
775 Supplementary Figure 4. (B) Detection of differentially expressed proteins in the PM fraction 776 of cDC and B cells of WT versus Marchf1/- and WT versus Marchf8-/- mice. Equivalent 777 amounts of PM fractions (based on cell count) of three biological replicates were analyzed by 778 mass spectrometry and semi-quantitative proteomics in three technical replicates. Proteins 779 detected in both WT and Marchf1 $^{-/-}$or Marchf8 $8^{-/-} \mathrm{cDC} / \mathrm{B}$ cells were displayed in volcano plots 780 (1020 proteins for WT vs. Marchf1/-/ cDC, 922 proteins for WT vs. Marchf8 $8^{-/-}$cDC, 1275 781 proteins for WT vs. Marchf1 ${ }^{-/-}$B cells and 1819 proteins for WT vs. Marchf8 $8^{-/-}$B cells) with 782 differentially expressed proteins [red dots] identified based on two-fold ratio ( $\log 2$ protein ratio $783>1$ or $<1$ ) and significance (5\% FDR) across three biological replicates, each measured in 784 technical triplicates. The known MARCH1 substrates, MHC II (H2-Aa and H2-Ab1) and CD86 785 in B cells and cDC, are highlighted in green in each volcano plot.

786

787 Figure 6. Ubiquitination of MHC II, CD86 and putative substrates by MARCH1 and 788 MARCH8 in non-haemopoietic antigen presenting cells. (A) Surface expression of MHC II, 789 CD86, CD80, CD40, CD44, CD95 and CD98 in medullary and cortical thymic epithelial cells 790 (mTEC and cTEC) purified from WT, Marchf1 ${ }^{-/-}$and Marchf8 $8^{-/-}$mice. (B) Surface expression 791 of MHC II and CD86 in endothelial cells, type I and type II alveolar epithelial cells (AEC) as 792 well as bronchiolar epithelial cells, purified from the lung of WT, Marchf1/- and Marchf8 ${ }^{-/-}$ 793 mice. In all cases a fluorescence-minus-one (FMO) control was included, for which cells were 794 incubated with the corresponding multi-colour staining panel, excluding the fluorescently 795 labelled antibody species of interest. Bars represent mean \pm SD with each symbol representing 796 an individual mouse $(\mathrm{n}=5)$. Statistical analysis was performed using one-way ANOVA 797 followed by Sidak's multiple comparisons test. $* * * * p<0.0001, * * * p<0.0002, * * p<0.002$, $798 * \mathrm{p}<0.03$, n.s. not significant. 
800

\section{Supplementary Figure 1}

802 Representative flow cytometry gating strategies for the identification of cell populations of 803 interest in blood, spleen, subcutaneous lymph nodes (LN), thymus, peritoneal cavity and lung. 804 In all cases cell doublets and dead cells were identified and excluded based on forward and 805 side scatter (FSC and SSC) as well as staining with propidium iodide (PI), diamidino

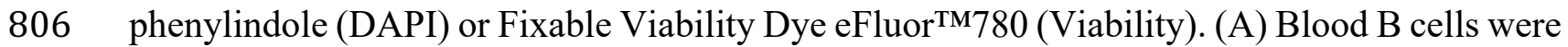
807 identified as $\mathrm{CD} 19^{+} \mathrm{B} 220^{+}$. (B) Splenic B cells, macrophages and T cells were identified from 808 whole splenocyte suspensions as $\mathrm{CD} 19^{+} \mathrm{B} 220^{+}, \mathrm{F} 4 / 80^{+} \mathrm{CD} 64^{+}$and $\mathrm{TCR} \beta^{+} \mathrm{CD} 3^{+}$respectively 809 with further discrimination of $\mathrm{CD}^{+}$and $\mathrm{CD}^{+} \mathrm{T}$ cells. Splenic DC were identified from low810 density splenocyte suspensions, with pDC identified as Siglec- $\mathrm{H}^{+}$BST-2 $2^{+}$and cDC as B220$811 \mathrm{CD}^{-} 9^{-} \mathrm{CD} 11 \mathrm{c}^{+} \mathrm{MHC} \mathrm{II}^{+}$, with further discrimination of $\mathrm{cDC} 1$ as $\mathrm{CD} 11 \mathrm{~b}^{-} \mathrm{CD}^{+}$and $\mathrm{cDC} 2$ as $812 \mathrm{CD}_{11 \mathrm{~b}^{+} \mathrm{CD} 8}$. Splenic granulocytes and monocytes were identified from whole splenocyte

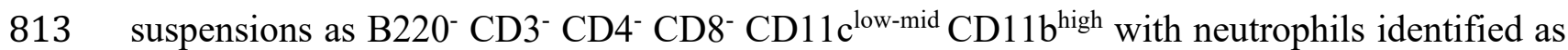
$814 \mathrm{Ly} \mathrm{G}^{+}$, eosinophils as Ly6G- SSC-H $\mathrm{H}^{\text {high }}$ Ly6C $\mathrm{C}^{\text {low-mid }}$, patrolling monocytes as Ly6G- Ly6Clow815 mid SSC-H ${ }^{\text {low }}$ and inflammatory monocytes as Ly6G- Ly6C ${ }^{\text {high }}$ SSC-H ${ }^{\text {low }}$ (as described in 816 Liyanage et al. [73]). (C) cDC from subcutaneous LN were identified from low-density cell 817 suspensions, with resident $\mathrm{cDC}$ identified as $\mathrm{CD} 11 \mathrm{c}^{\text {high }} \mathrm{MHC} \mathrm{II}^{\mathrm{mid}}$ and migratory $\mathrm{cDC}$ 818 identified as CD11 $\mathrm{c}^{\text {mid }} \mathrm{MHC} \mathrm{II}^{\text {high }}$ and further discrimination of $\mathrm{cDC} 1$ as Sirpa $\alpha^{-} \mathrm{XCR} 1+$ and $819 \mathrm{cDC}^{2}$ as $\mathrm{Sirpa}^{+} \mathrm{XCR}^{-}$. B cells, macrophages and T cells from subcutaneous LN were 820 identified from whole cell suspensions as $\mathrm{CD}^{+} 9^{+} \mathrm{B}_{220^{+}}, \mathrm{F} 4 / 80^{+} \mathrm{MHC} \mathrm{II}^{+}$and $\mathrm{CD}^{+}$ 821 respectively with further discrimination of $\mathrm{CD}^{+}$and $\mathrm{CD} 8^{+} \mathrm{T}$ cells. (D) Thymic cDC were 822 identified from low-density cell suspensions as B220- $\mathrm{NK} 1.1^{-} \mathrm{CD} 11 \mathrm{c}^{+} \mathrm{MHC} \mathrm{II}^{+}$, with further 823 discrimination of $\mathrm{cDC} 1$ as $\operatorname{Sirp} \alpha^{-} \mathrm{XCR}^{+}$and $\mathrm{cDC} 2$ as Sirp $\alpha+\mathrm{XCR} 1-$ (as described in Ardouin 824 et al. [74]). Thymic epithelial cells (TECs) were identified from whole thymocyte suspensions 825 as $\mathrm{CD}^{-} 5^{-} \mathrm{EpCAM}^{+}$, with further discrimination of cortical TECs (cTECs) as UEA-1- Ly51 ${ }^{+}$ and medullary TECs (mTECs) as UEA-1 ${ }^{+}$Ly51 ${ }^{-}$(as described in Liu et al. [9]). (D) Peritoneal macrophages were identified as $\mathrm{CD}_{11 b^{+}} \mathrm{MerTK}^{+}$, with further discrimination of small 828 peritoneal macrophages as F4/80 ${ }^{\text {low }}$ MHC II ${ }^{\text {high }}$ and large peritoneal macrophages as F4/80 high 829 MHC II ${ }^{\text {mid-high }}$ (as described in Bain et al. [75]). Peritoneal B cells were identified as MerTK-

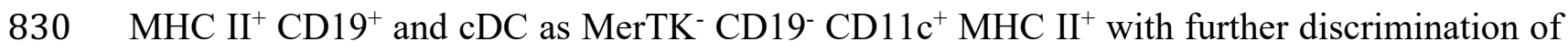
$831 \mathrm{cDC}^{\mathrm{a}}$ as CD11 $\mathrm{b}^{-} \mathrm{XCR}^{+}$and $\mathrm{cDC} 2$ as $\mathrm{CD} 11 \mathrm{~b}^{+} \mathrm{XCR}^{-}$. (E) Haemopoietic cells in the lung were 832 identified as $\mathrm{CD}_{4} 5^{+}$with $\mathrm{pDC}$ as $\mathrm{CD} 11 \mathrm{c}^{\text {low-mid }} \mathrm{BST}-2^{+}$and macrophages as $\mathrm{CD}^{+} 4^{+} \mathrm{MerTK}^{+}$, 
with further discrimination of interstitial macrophages as Siglec-Flow $\mathrm{CD} 11 \mathrm{~b}^{\text {high }}$ and alveolar 834 macrophages as Siglec-F ${ }^{\text {high }}$ CD1 $1 b^{\text {mid }}$ (as described in Svedberg et al. [76]). Lung B cells were

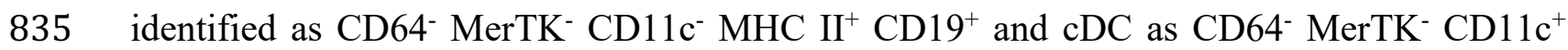
$836 \mathrm{MHC} \mathrm{II}^{+}$with further discrimination of $\mathrm{cDC} 1$ as $\mathrm{CD} 11 \mathrm{~b}^{-} \mathrm{XCR}^{+}$and $\mathrm{cDC} 2$ as $\mathrm{CD} 11 \mathrm{~b}^{+} \mathrm{XCR} 1^{-}$ 837 . Lung granulocytes and monocytes were identified as B220- CD3- CD4- CD8- CD11 c $^{\text {low-mid }}$ $838 \mathrm{CD} 1 \mathrm{~b}^{\text {high }}$ with neutrophils identified as Ly6G ${ }^{+}$, eosinophils as Ly6G- SSC-H ${ }^{\text {high }}$ Ly6Clow-mid, 839 patrolling monocytes as $\mathrm{Ly} 6 \mathrm{G}^{-}$Ly6C $\mathrm{C}^{\text {low-mid }} \mathrm{SSC}-\mathrm{H}^{\text {low }}$ and inflammatory monocytes as Ly6G ${ }^{-}$ 840 Ly6C ${ }^{\text {high }}$ SSC-H ${ }^{\text {low }}$ (as described in Liyanage et al. [73]). Non-haemopoietic cells in the lung 841 were identified as CD45- with endothelial cells identified as $\mathrm{EpCAM}^{\text {low-mid }} \mathrm{CD}^{-} 1^{+} \mathrm{Sca}-1^{+}$and 842 epithelial cells as EpCAM ${ }^{\text {mid-high }} \mathrm{CD}^{-} 1^{-}$. Further discrimination of epithelial cells was carried 843 out based of CD24, EpCAM and MHC II expression (as described in Nakano et al. [61] and 844 Hasegawa et al. [62]) with bronchiolar epithelial cells identified as EpCAM ${ }^{\text {high }}$ CD24 $4^{\text {high }}$, type 845 II alveolar epithelial cells (AEC) identified as EpCAM ${ }^{\text {high }}$ CD24 ${ }^{\text {mid }}$ MHC II ${ }^{\text {high }}$ (red) and type 846 I AEC identified as EpCAM ${ }^{\text {mid }} \mathrm{CD} 24^{\text {low }} \mathrm{MHC} \mathrm{II}^{\text {low }}$ (green).

847 A comparison of the representative flow cytometry gating strategies for the identification of all 848 cell populations of interest between WT, Marchf1 $1^{-/-}$and Marchf $^{-/-}$mice is shown in 849 Supplementary Figure 2.

850

\section{Supplementary Figure 2}

852 Comparison of representative flow cytometry gating strategies for the identification of various 853 cell populations in (A) blood, (B) spleen, (C) subcutaneous lymph node, (D) thymus, (E) peritoneal cavity and (F) lung from WT, $\mathrm{Marchf1}^{-/-}$and $\mathrm{Marchf}^{-/-}$mice. A detailed description of the gating strategies for each individual cell population of interest is presented in Supplementary Figure 1.

857

\section{Supplementary Figure 3}

859 Surface expression of MHC II and CD86 in peritoneal cDC from WT, Marchf1 -/- $^{-1}$ and Marchf8-

860 /- mice or from mice deficient in both MARCH1 and MARCH8 (Marchf1 ${ }^{-/-}$x Marchf8 ${ }^{-/-}$). A

861 fluorescence-minus-one (FMO) control was included, for which cells were incubated with the 862 corresponding multi-colour staining panel, excluding the fluorescently labelled antibody 863 species of interest (i.e. anti-CD86 or anti-MHC II mAb). Bars represent mean \pm SD with each 864 symbol representing an individual mouse $(n=4)$. Statistical analysis was performed using one865 way ANOVA followed by Sidak's multiple comparisons test. **** p $<0.0001, * * * \mathrm{p}<0.0002$, $866 * * \mathrm{p}<0.002, * \mathrm{p}<0.03$, n.s. not significant. 


\section{Supplementary Figure 4}

869 Gene ontology (GO) enrichment analysis of proteins detected in plasma membrane (PM)-

870 enriched and intracellular compartment (IC)-enriched microsome fractions of splenic cDC and

871 B cells purified from WT, Marchf1 ${ }^{-/}$or Marchf8 $^{-/-}$mice. PM fractions were purified from post-

872 nuclear supernatants of $\mathrm{mAb}$ surface stained $\mathrm{cDC}$ and $\mathrm{B}$ cells via magnetic immunoaffinity. IC

873 (intracellular compartments) was retrieved from the post-nuclear supernatant of homogenized

874 cells following PM fraction extraction. IC and PM fraction were analysed by semi-quantitative

875 mass spectrometry and GO term enrichment analysis was performed using the Bioconductor

876 clusterProfiler package [42] with GO-IDs grouped based on experimentally verified Gene

877 Ontology (GO) annotations.

878

\section{Supplementary Figure 5}

880 Surface expression of CD13, CD1d, CD6 and CD23 in B cells from WT, Marchf1 ${ }^{-/}$and

881 Marchf8 $^{-/-}$mice. A fluorescence-minus-one (FMO) control was included, for which cells were

882 incubated with the corresponding multi-colour staining panel, excluding the fluorescently 883 labelled antibody species of interest. 
Figure 1

A blood B
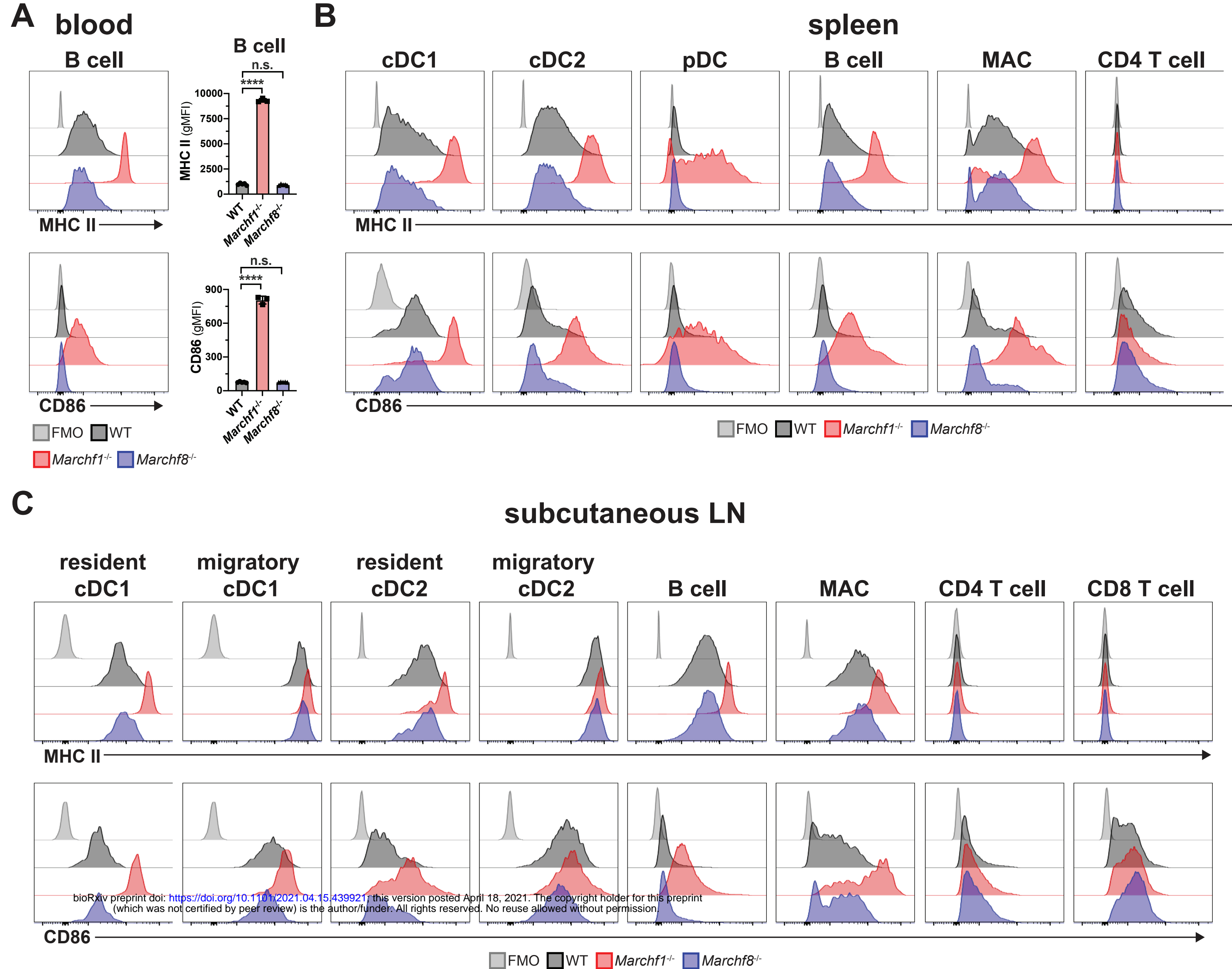

D

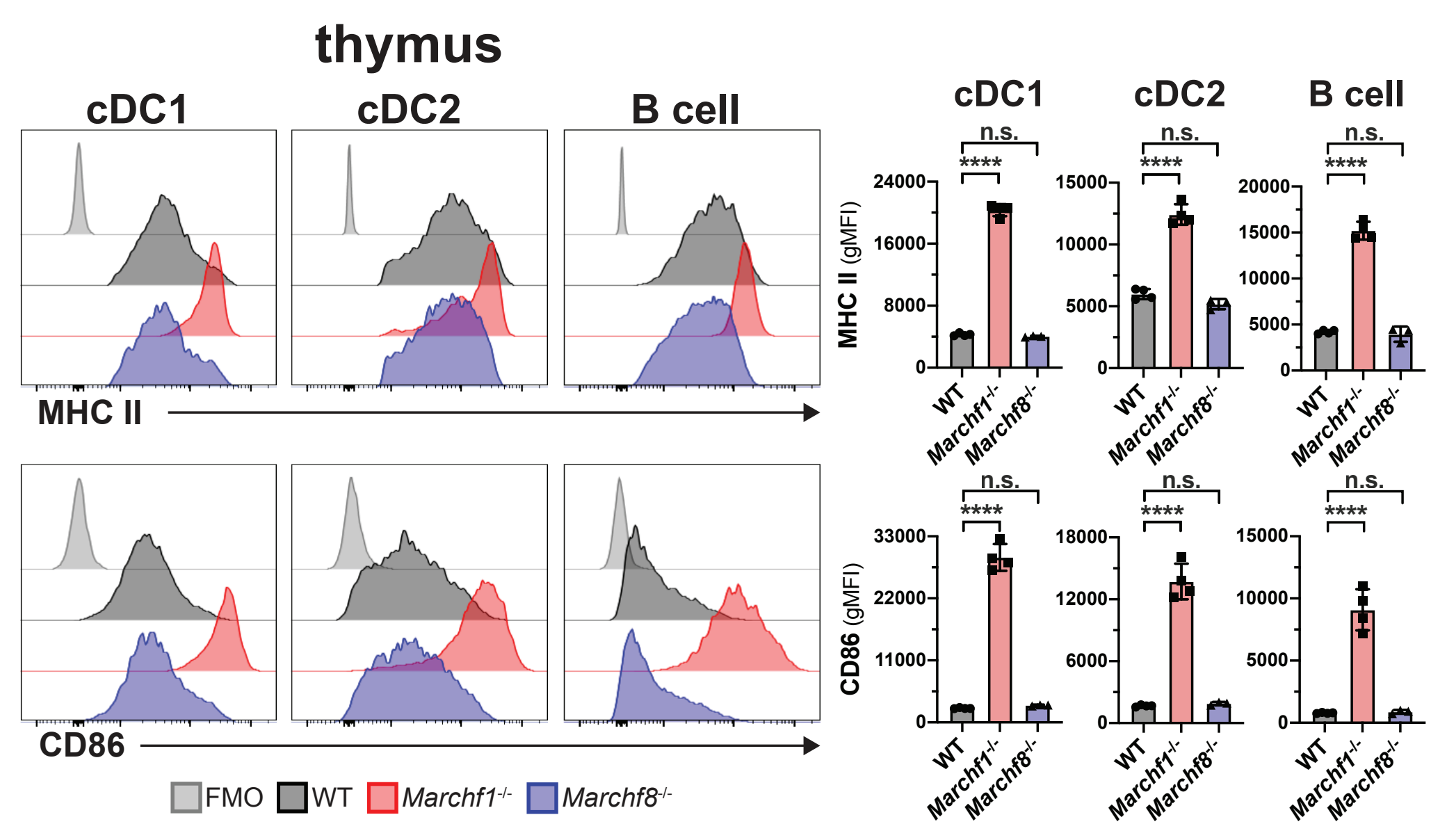

E

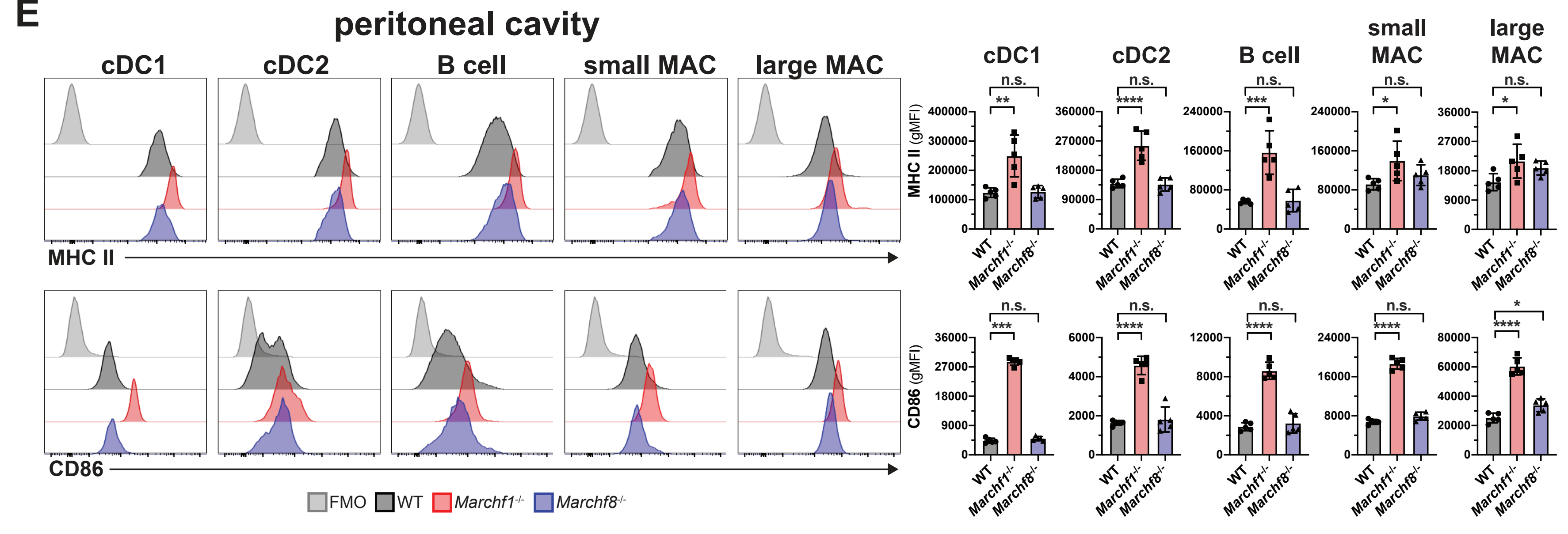

$\mathbf{F}$

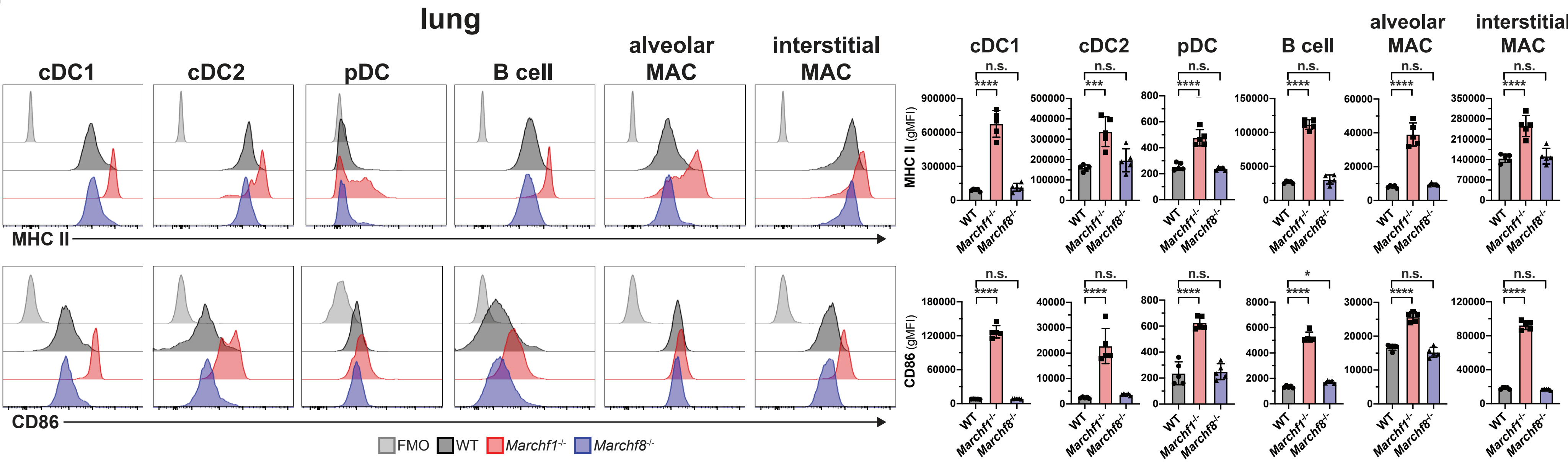


Figure 2

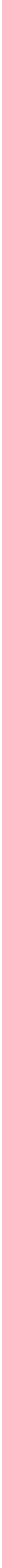


A

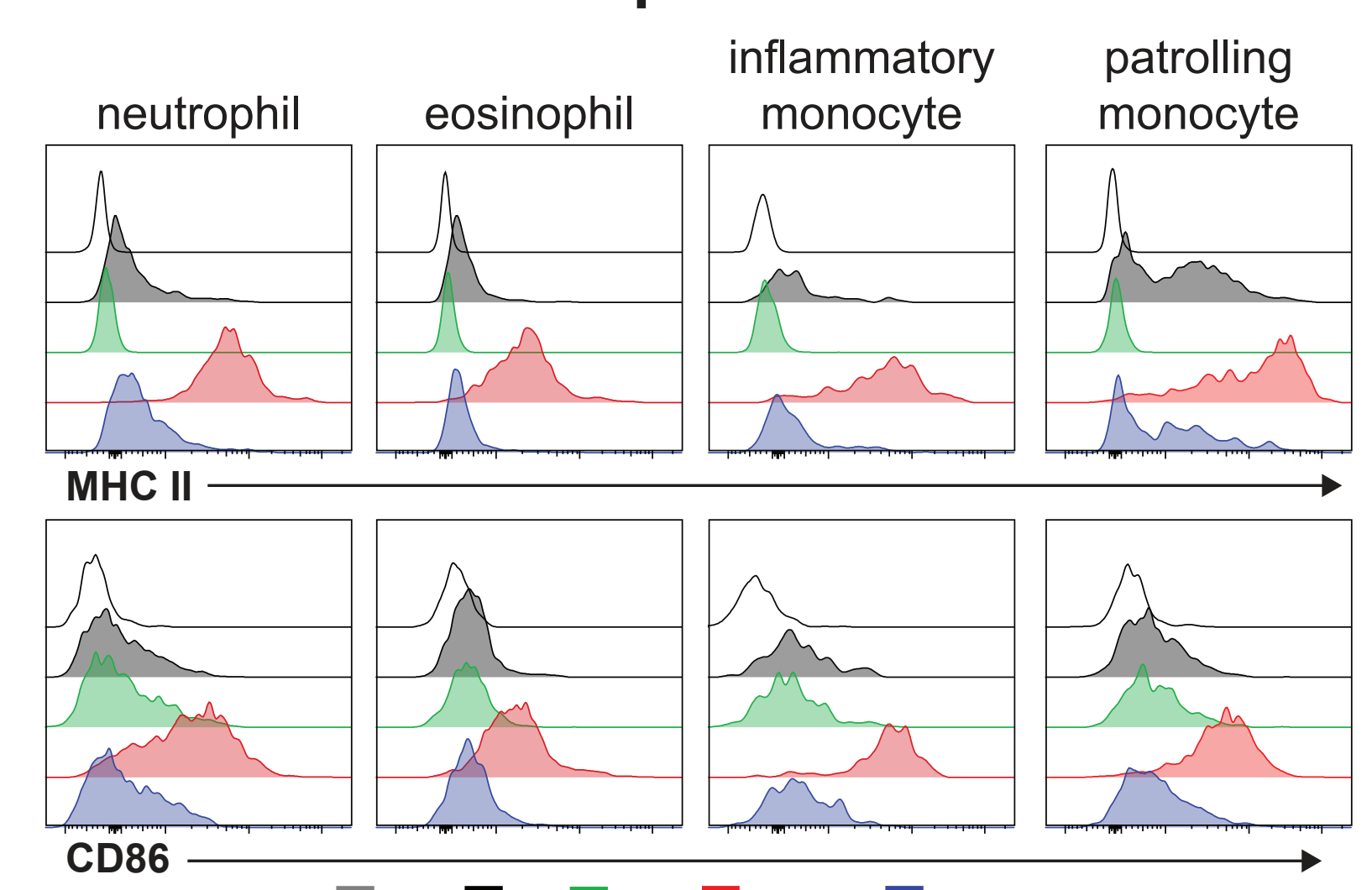

$\square$ FMO $\square$ WT $\square$ I-Ad $\square$ Marchf1 $1-\square$ Marchf8-

\section{spleen}

B

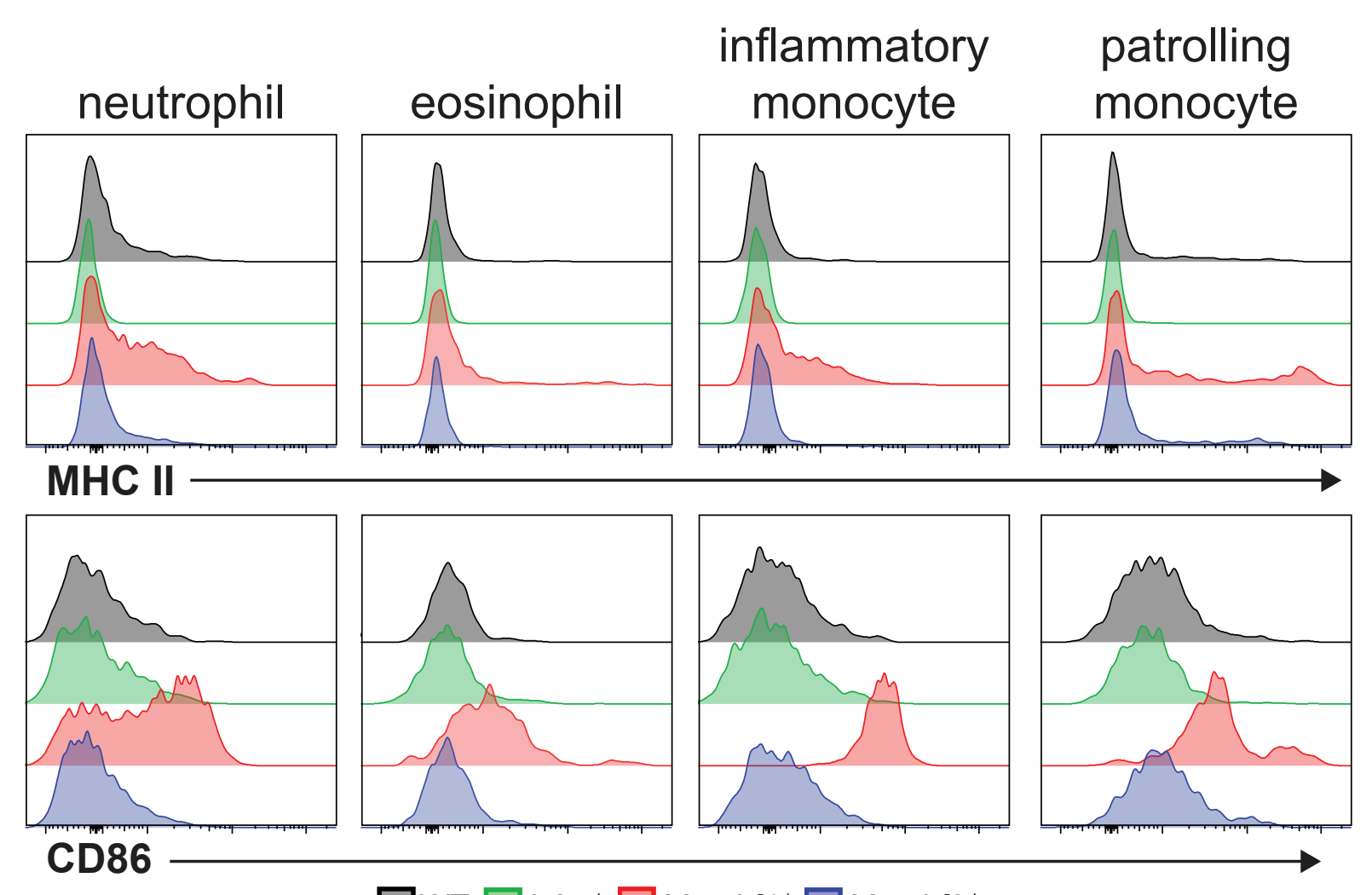

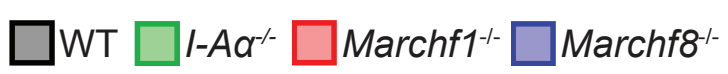

neutrophil eosinophil $\begin{array}{cc}\text { inflammatory patrolling } \\ \text { monocyte }\end{array}$
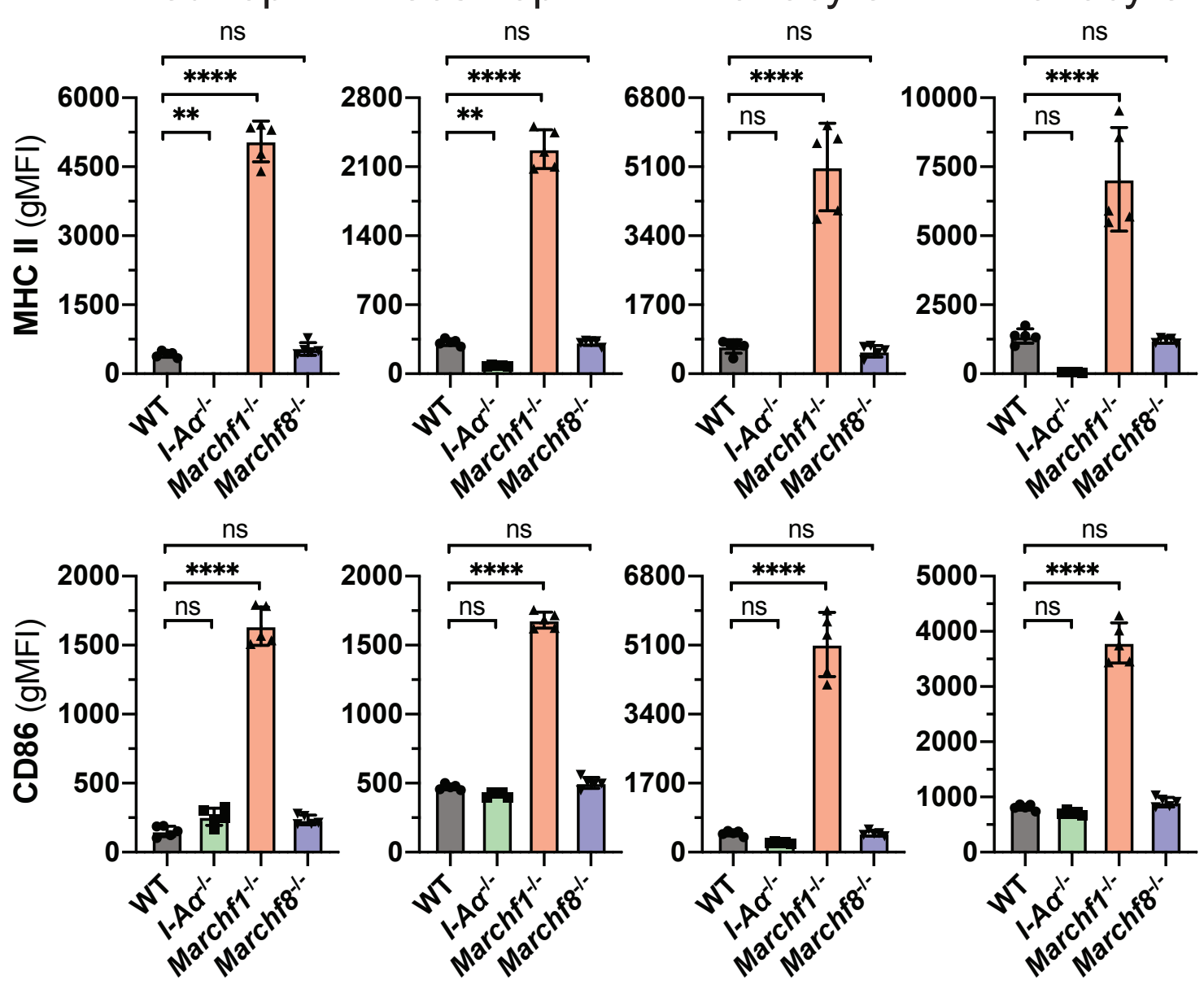

neutrophil
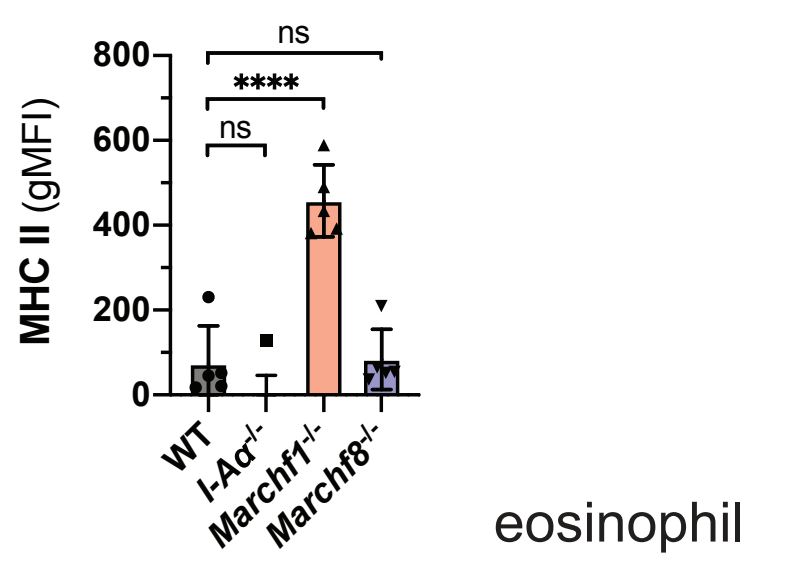

inflammatory
monocyte

patrolling
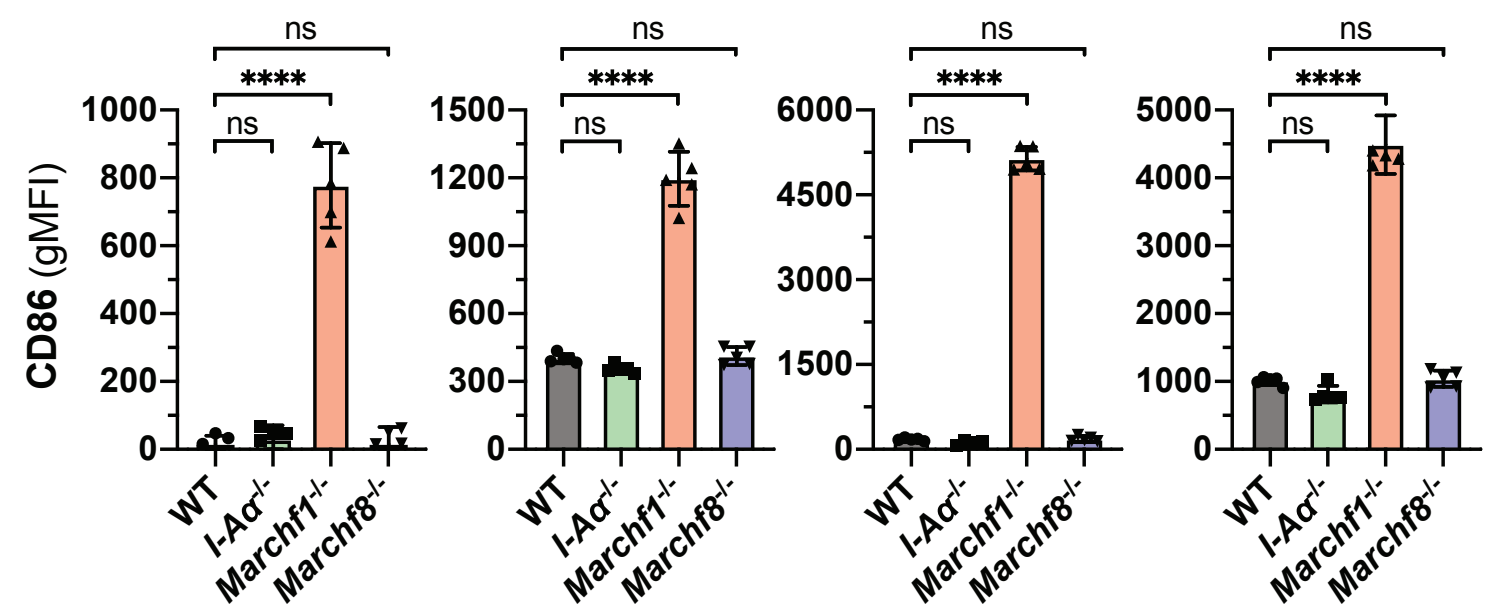
cDC

WT vs. Marchf1 ${ }^{-1-} \mathrm{CDC}$

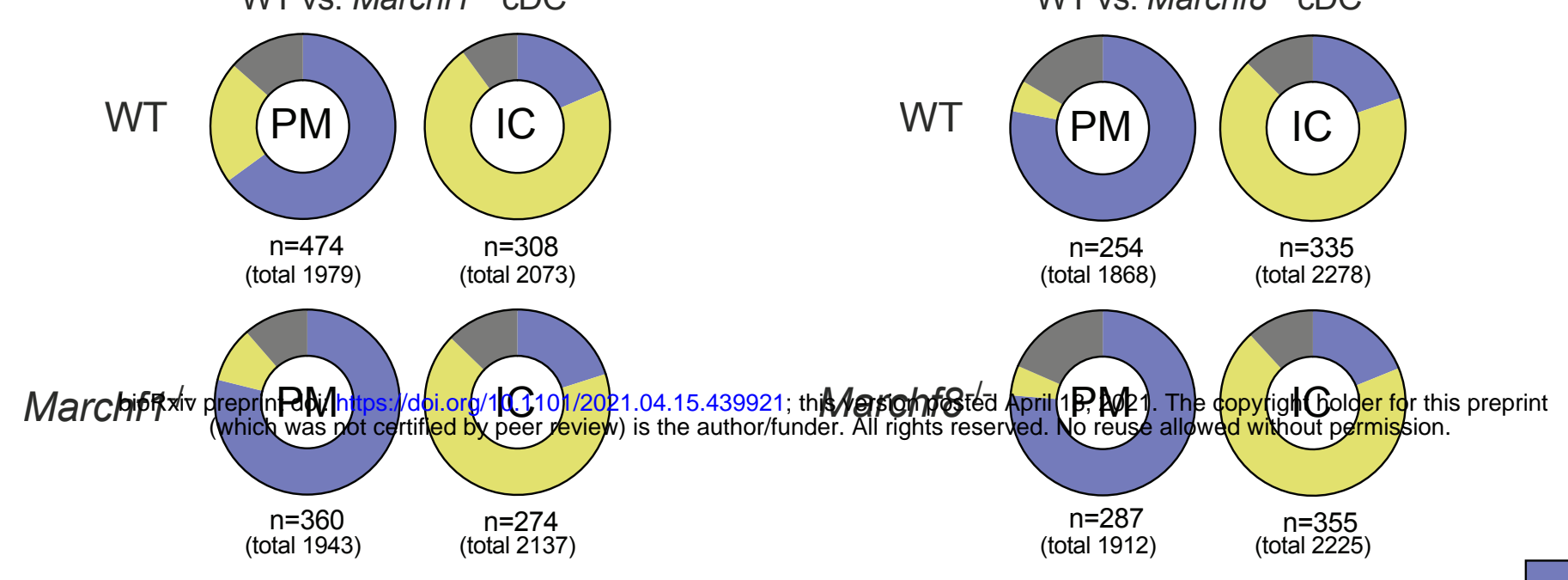

\section{B cell}

WT vs. Marchf1-1- B cell
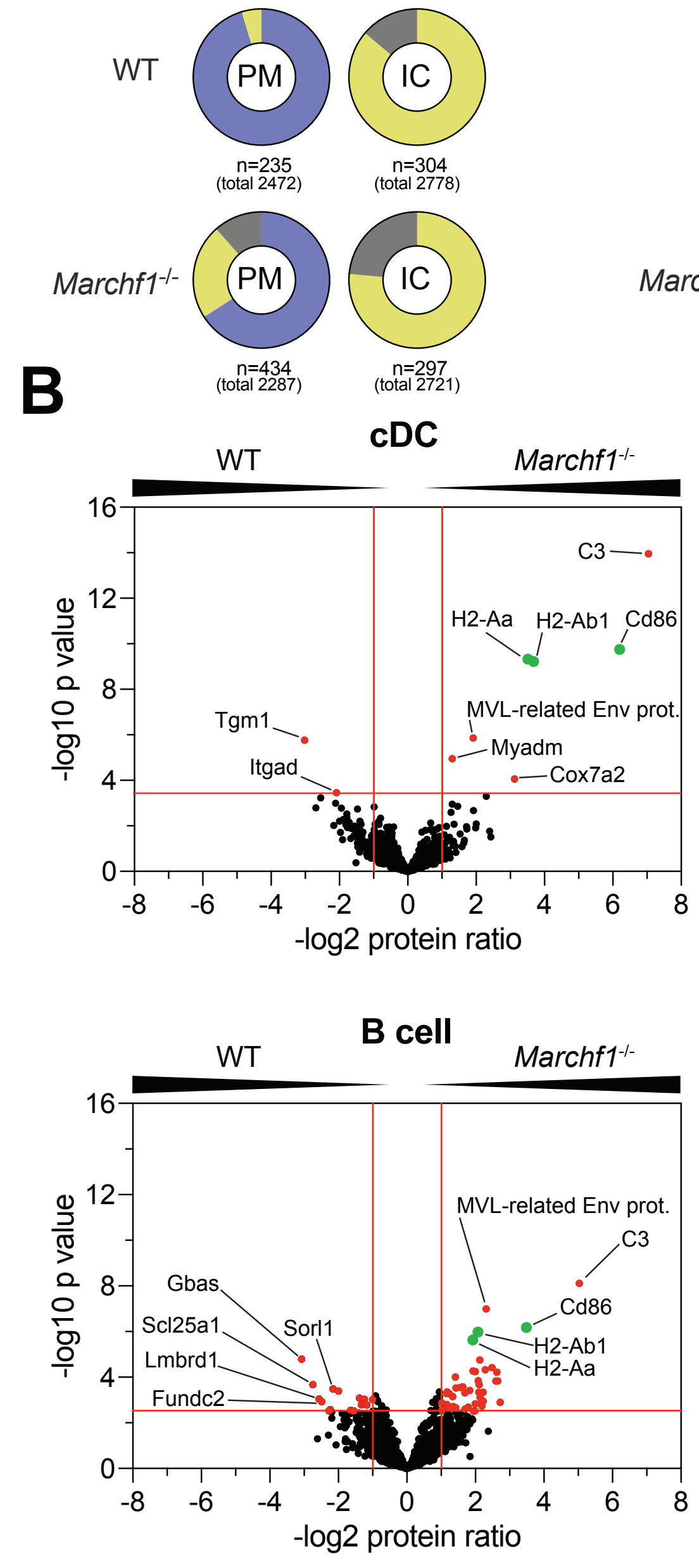

cDC

WT vs. Marchf8-/- $\mathrm{CDC}$

Cell surface Intracellular Others

\section{B cell}

WT vs. Marchf8-- B cell

WT
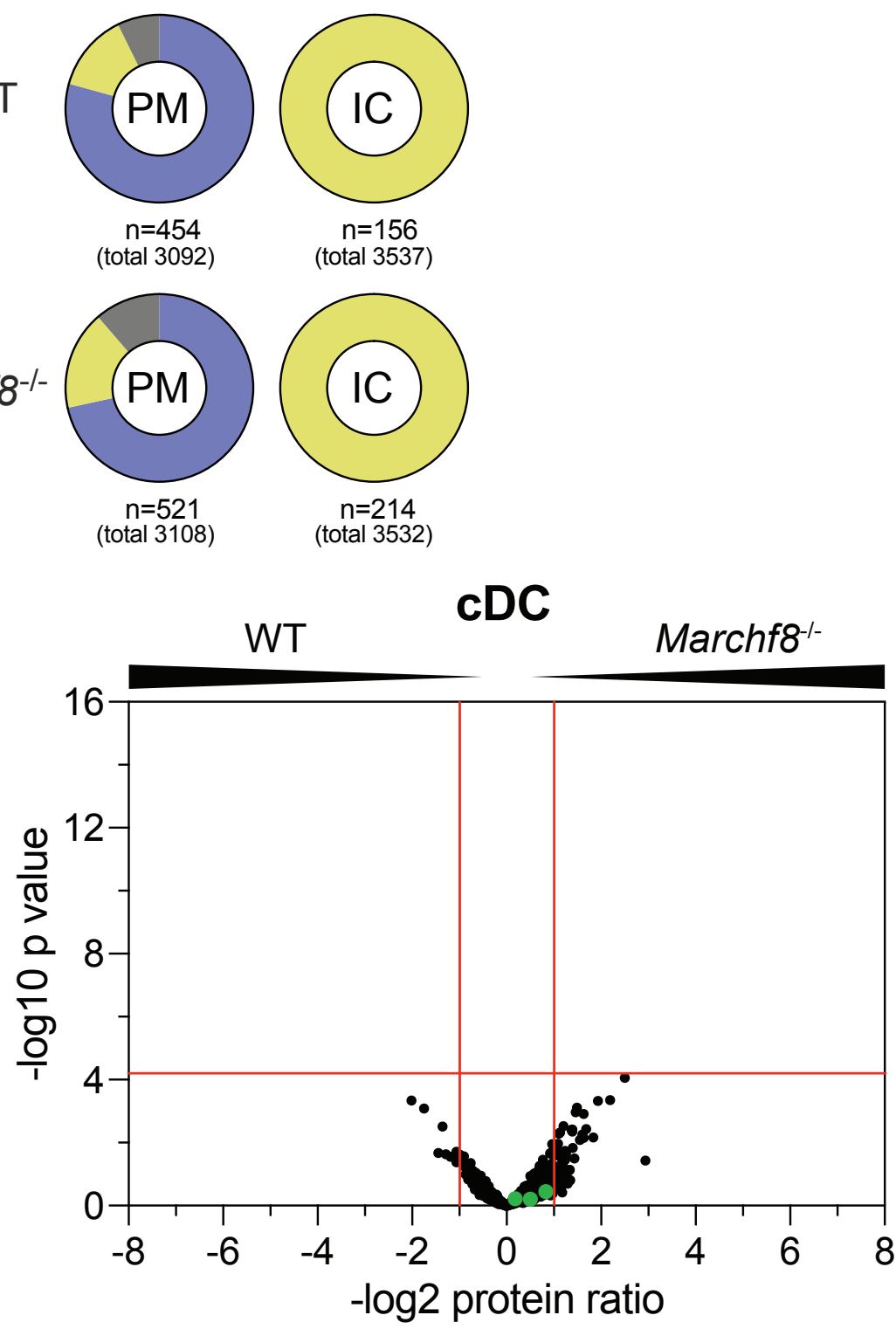

B cell

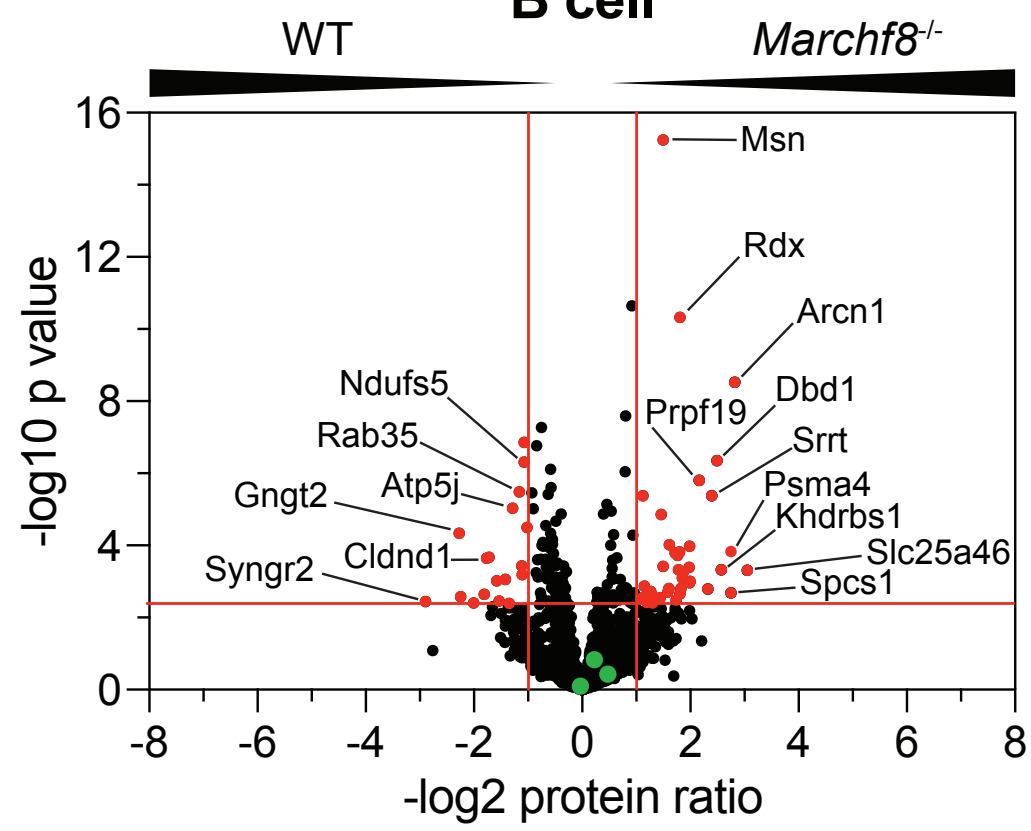




\section{Supplementary Figure 1}

A

B
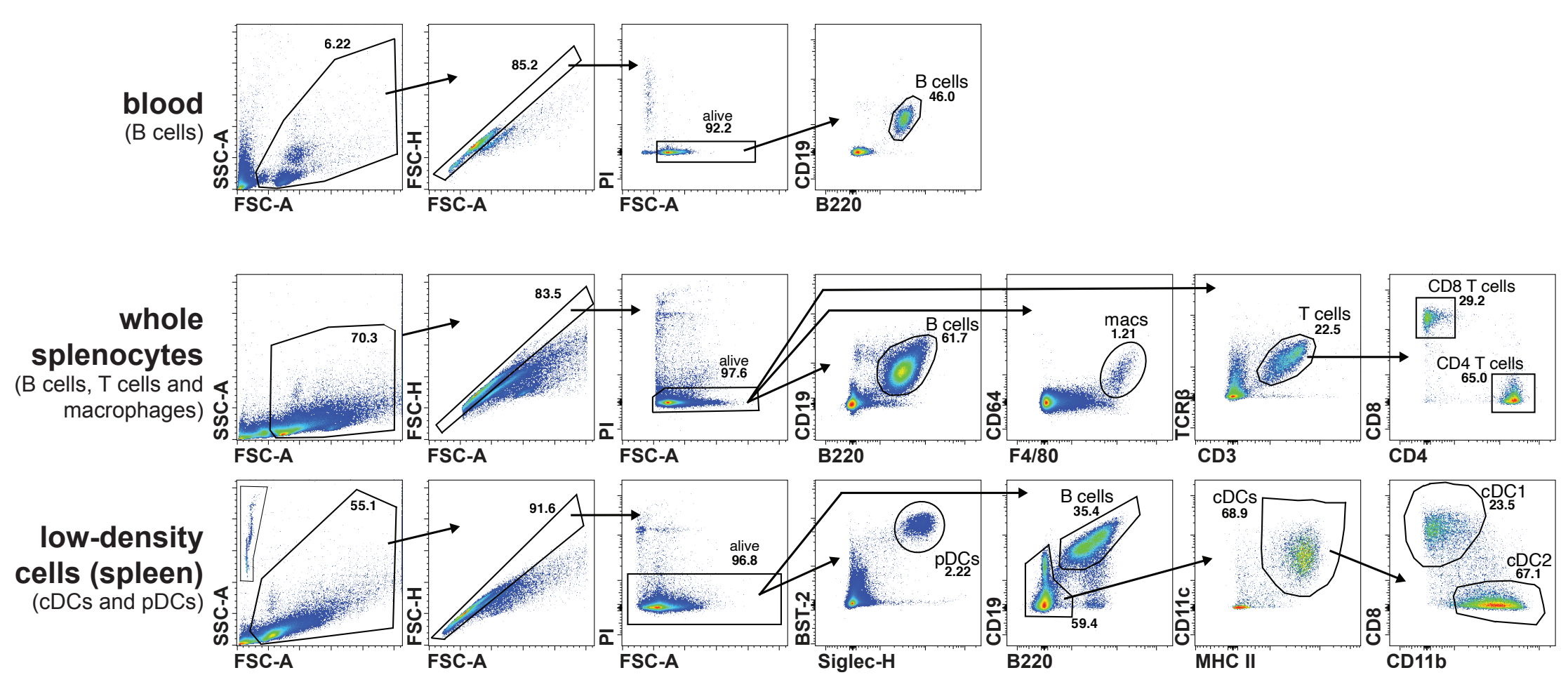

whole

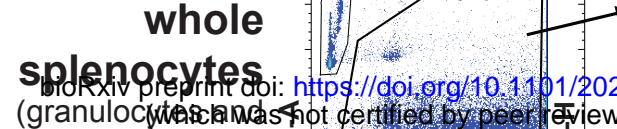

(granulocytasciandis
monocytes)

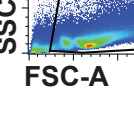

C

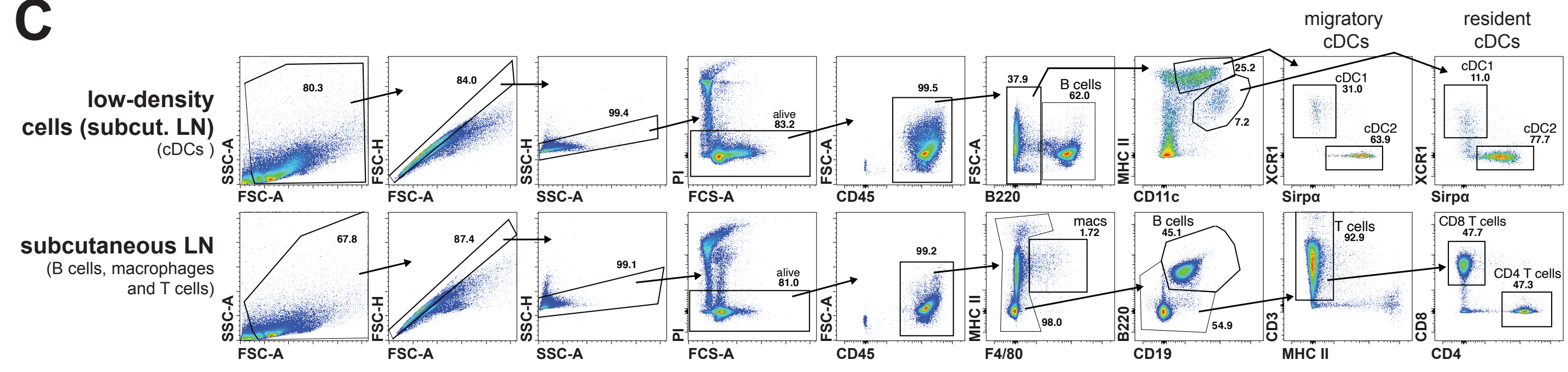

D
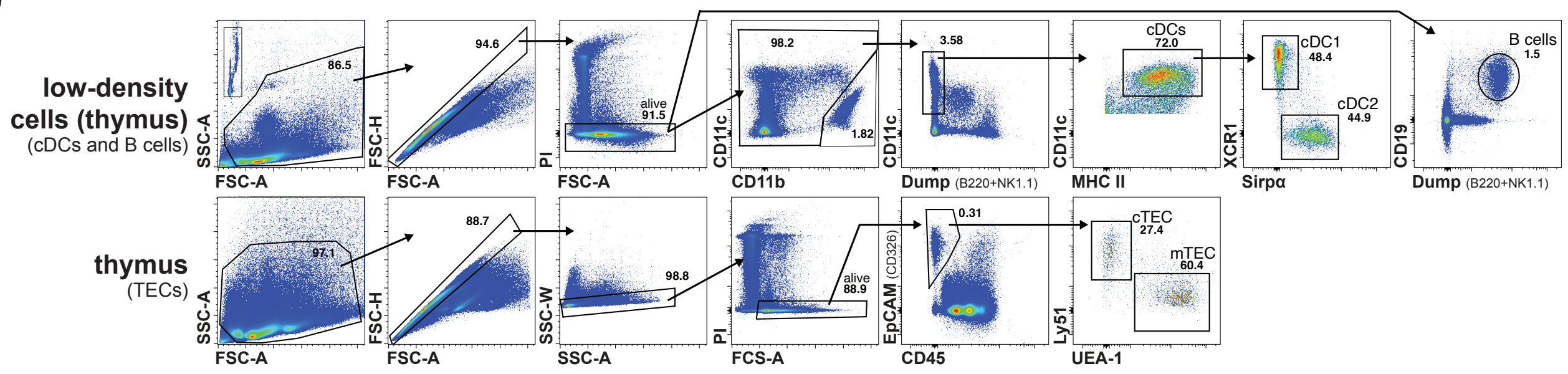

E

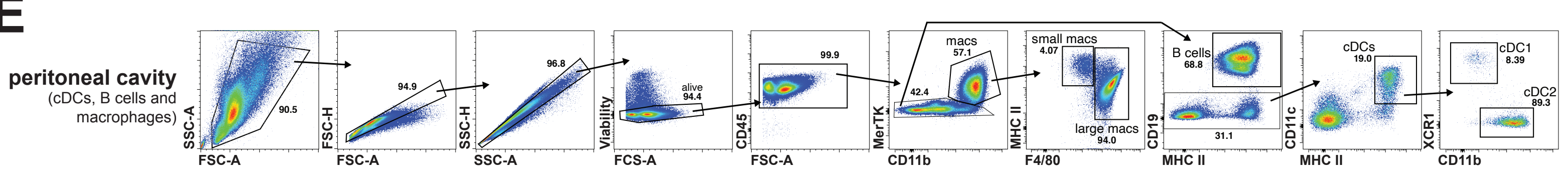

F

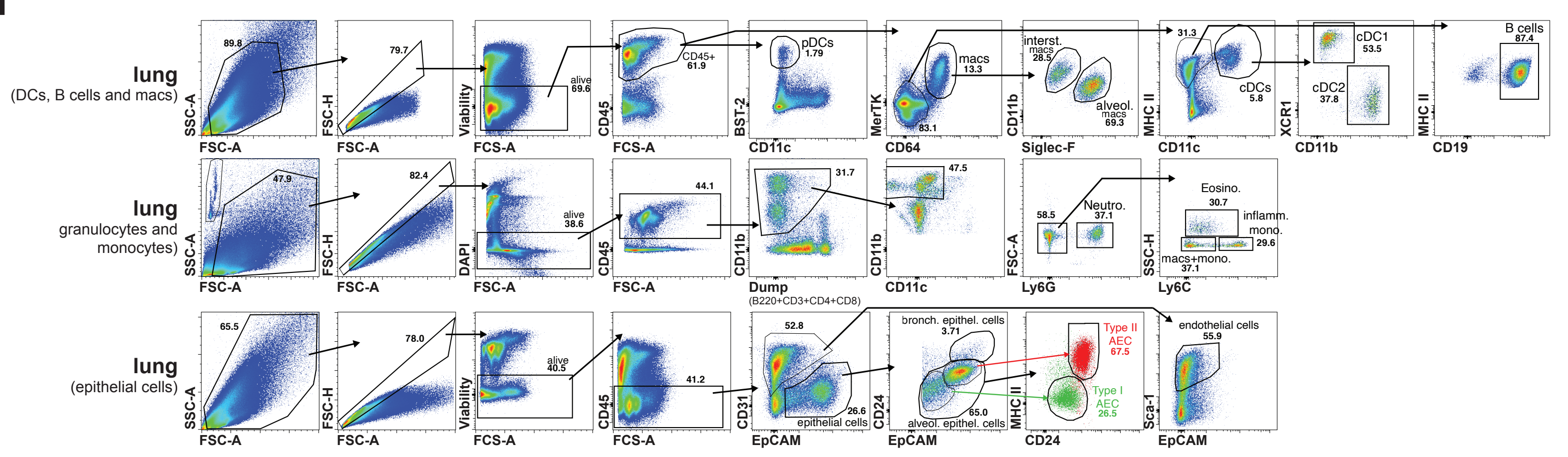



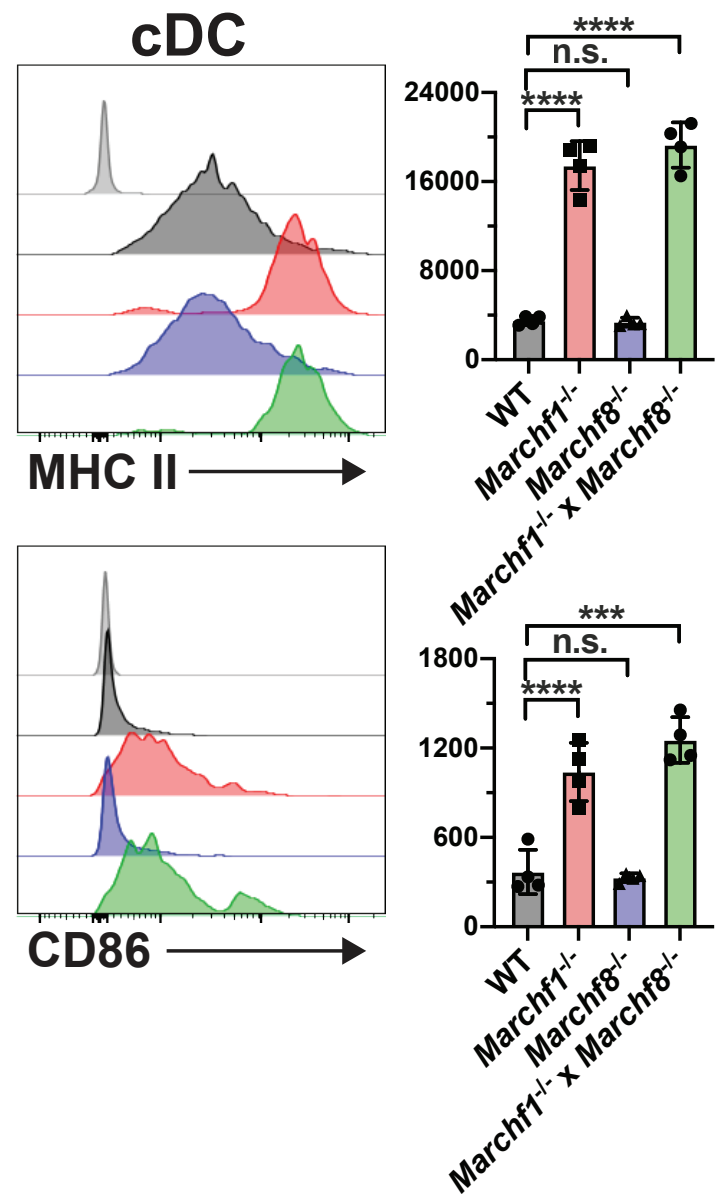

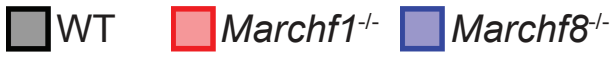

$\square$ FMO $\square$ Marchf1 $^{-1-} \times$ Marchf8 $^{-1-}$ 


\section{cDC}

WT vs. Marchf1-/-
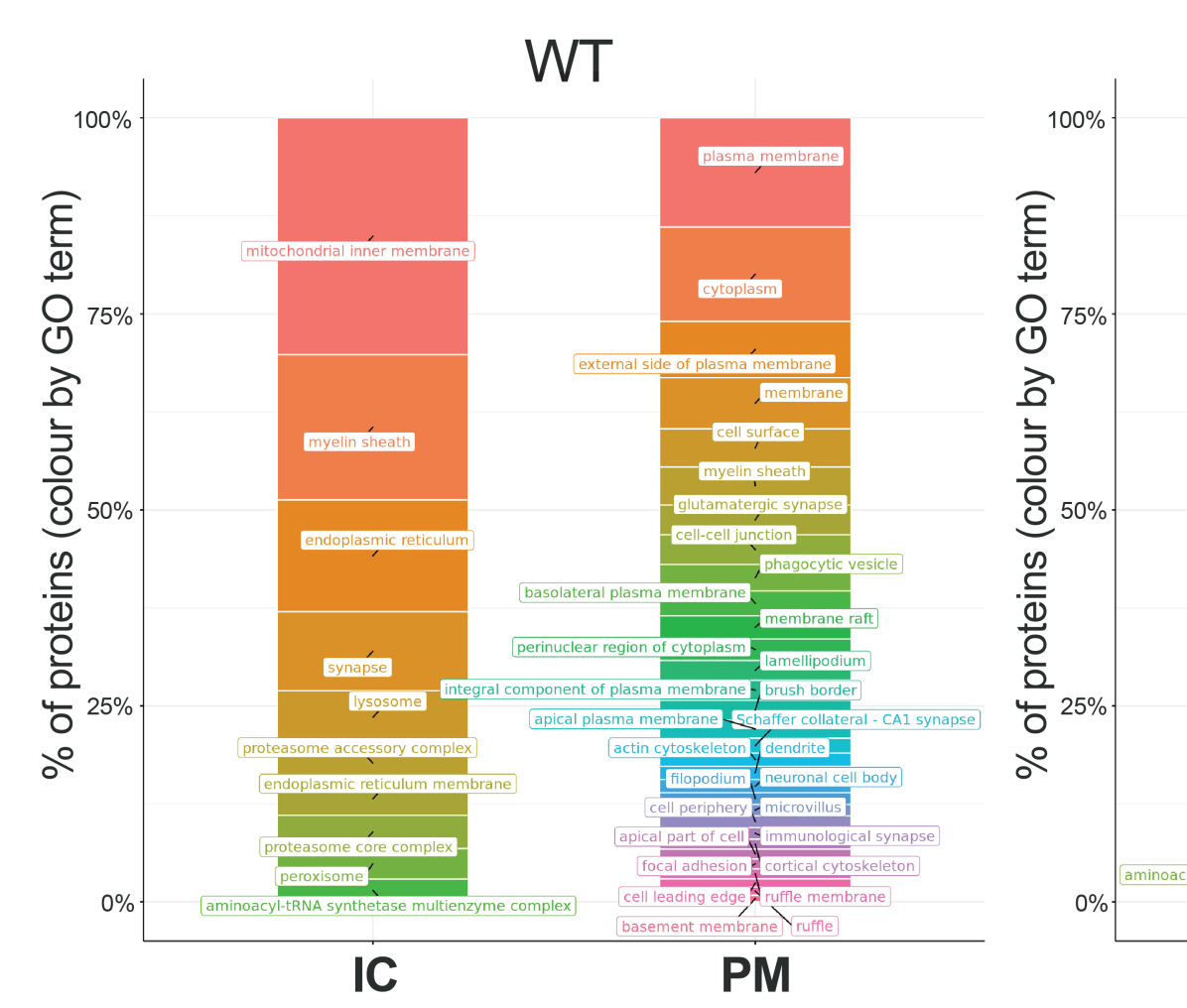

$\operatorname{Marchf1}^{-/}$

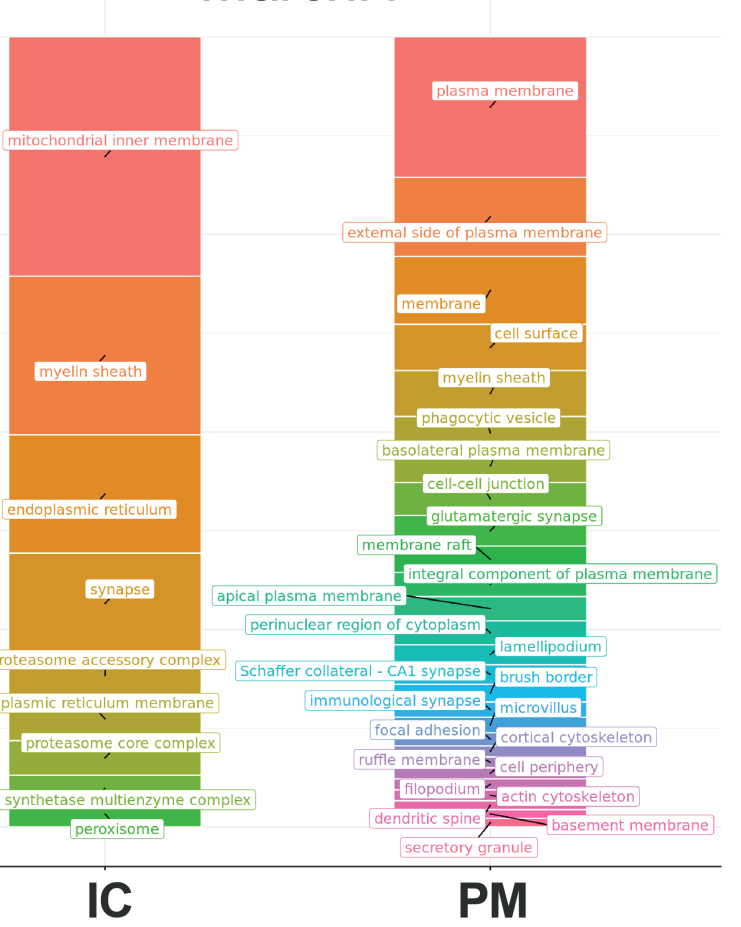

cDC

WT vs. Marchfo-/-
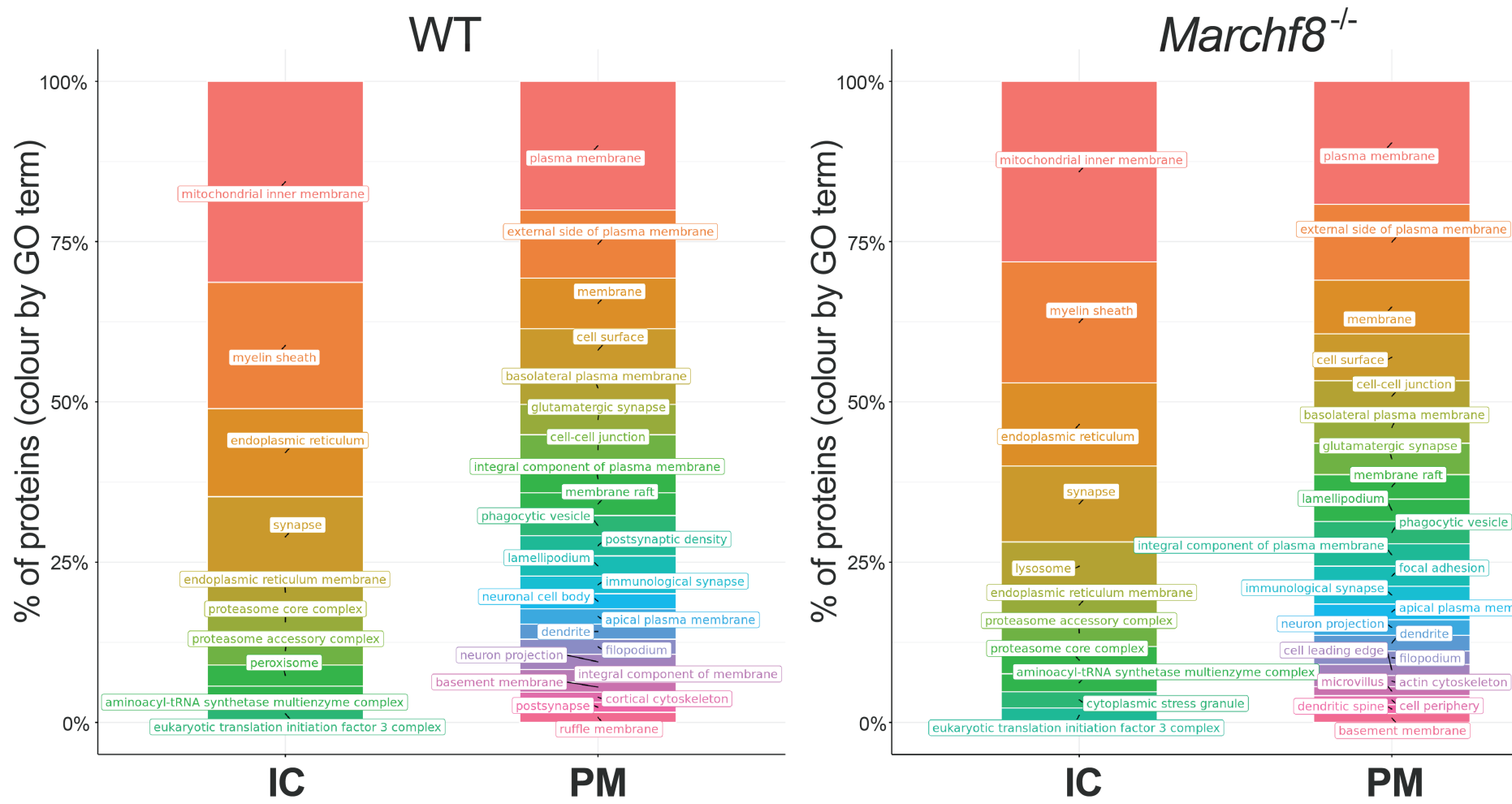

B cell

WT vs. Marchf1/-

WT

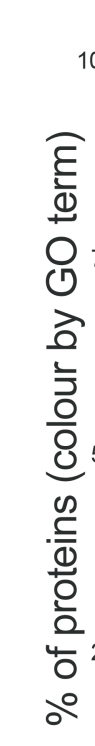

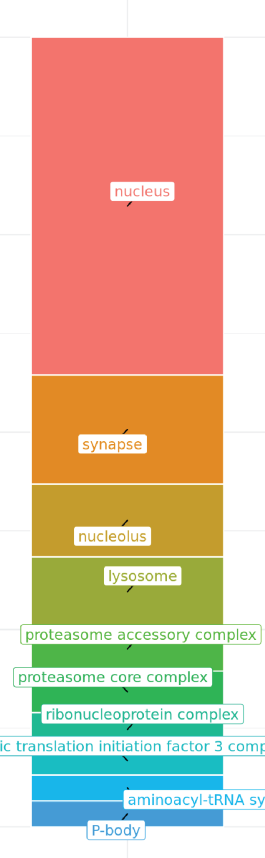

IC

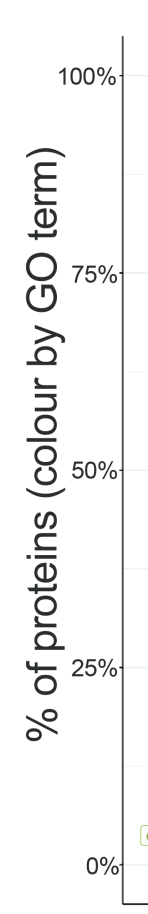

PM

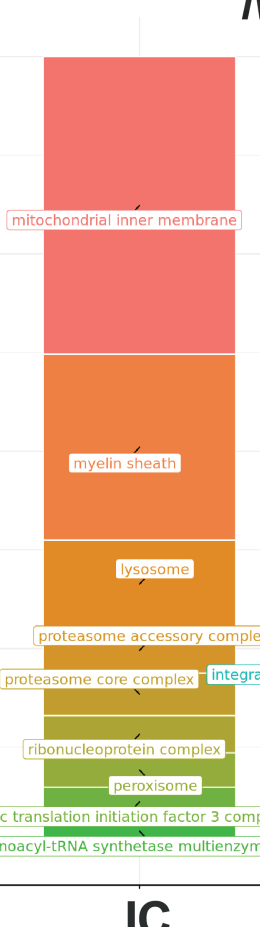

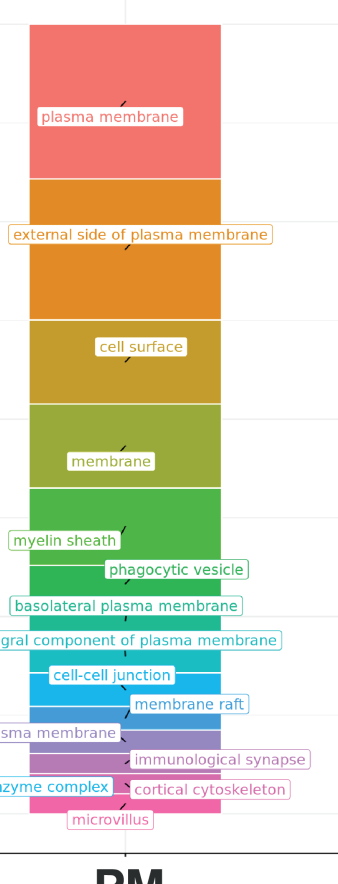

Marchf1 $^{-/-}$

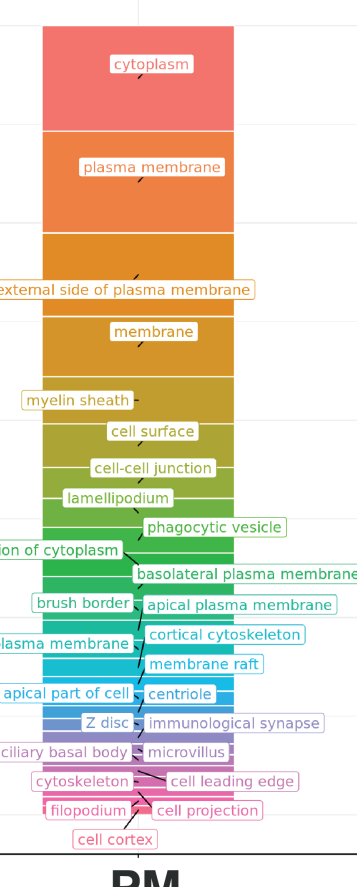

WT

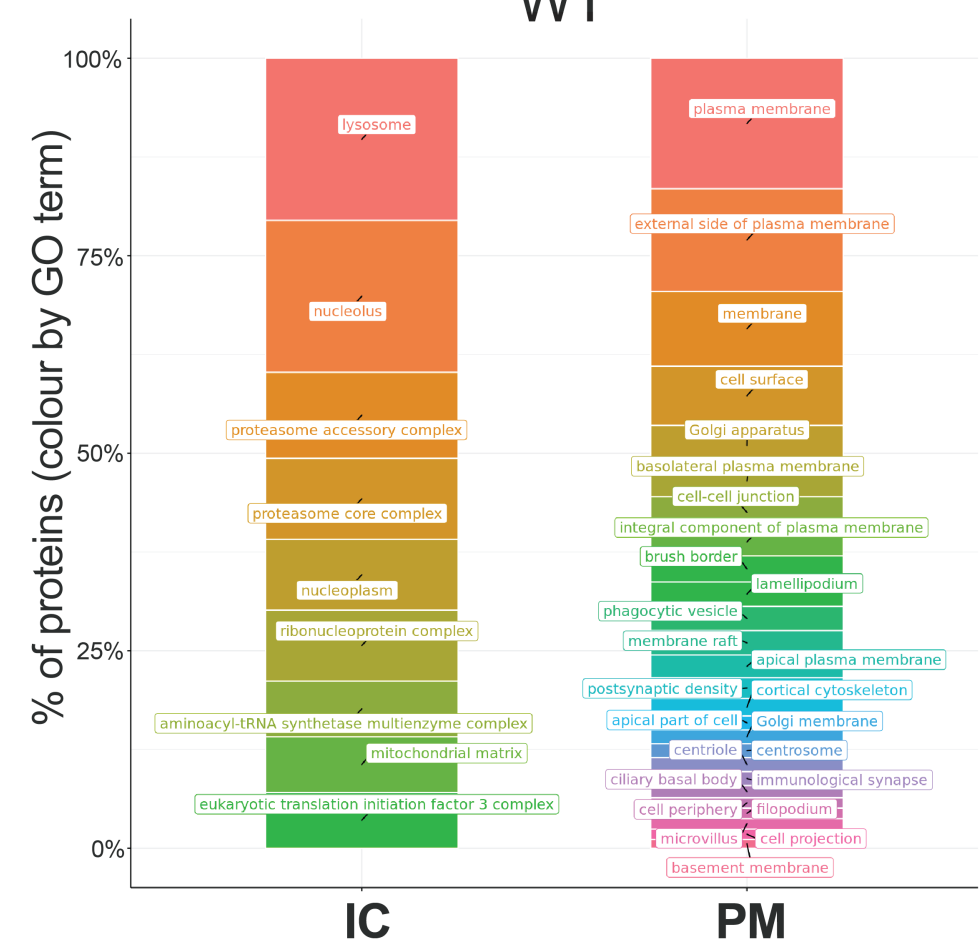

Marchf8 $^{-/-}$

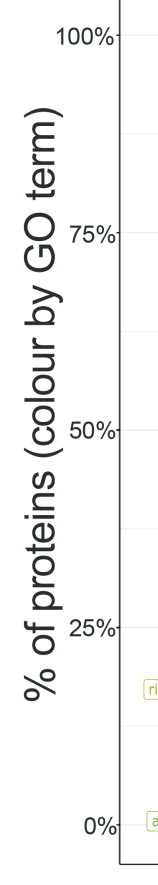

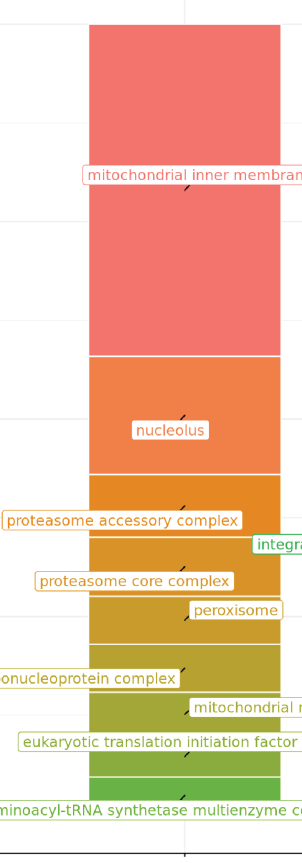

IC

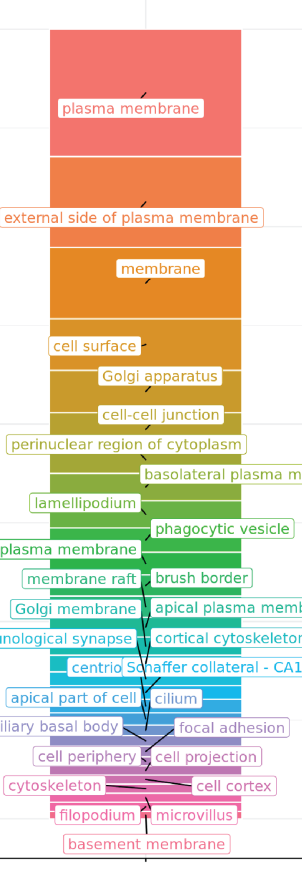


Supplementary Figure 5

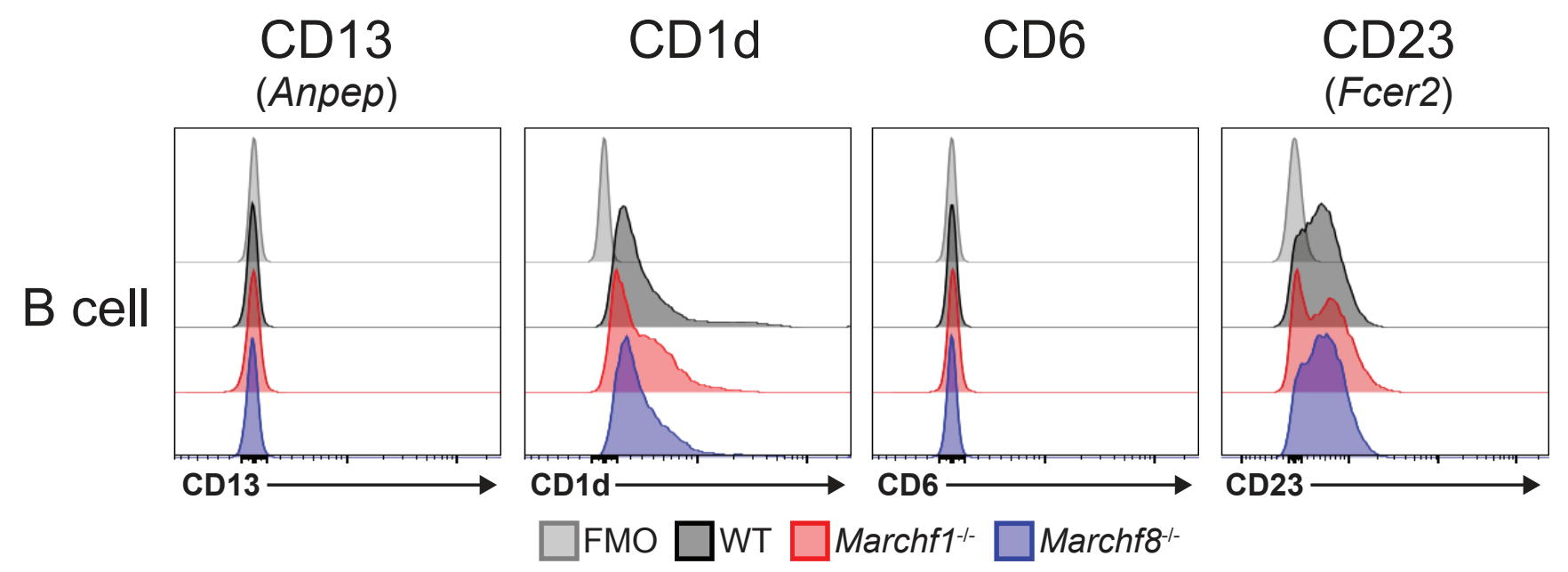


Supplementary Table 5: Significantly up/down-regulated proteins in the PM fraction of Marchf1/- $\mathrm{cDCs}$.

\begin{tabular}{|c|c|c|c|c|c|}
\hline Gene & Protein Names & $\begin{array}{l}\text { Log2 Fold } \\
\text { Change }\end{array}$ & $\begin{array}{l}-\log 10 p \\
\text { value }\end{array}$ & $\begin{array}{r}\text { Localisation } \\
\text { (based on GO-ID } \\
\text { of enrichment } \\
\text { analysis) }\end{array}$ & $\begin{array}{r}\text { Localisation (based } \\
\text { on UniProt) }\end{array}$ \\
\hline C3 & Complement C3 & 7.04 & 13.95 & $\begin{array}{r}\text { Extracellular, Cell } \\
\text { surface }\end{array}$ & $\begin{array}{r}\text { Extracellular region or } \\
\text { secreted }\end{array}$ \\
\hline Cd86 & T-lymphocyte activation antigen CD86 & 6.20 & 9.76 & $\begin{array}{r}\text { Plasma membrane, } \\
\text { Intracellular } \\
\text { membrane-bounded } \\
\text { organelle }\end{array}$ & $\begin{array}{r}\text { Cell membrane, Single- } \\
\text { pass type I membrane } \\
\text { protein }\end{array}$ \\
\hline H2-Aa & $\begin{array}{l}\mathrm{H}-2 \text { class II histocompatibility antigen, A-B alpha } \\
\text { chain }\end{array}$ & 3.51 & 9.33 & $\begin{array}{l}\text { Plasma membrane, } \\
\text { Early endosome }\end{array}$ & $\begin{array}{l}\text { Membrane, Single-pass } \\
\text { type I membrane protein }\end{array}$ \\
\hline$H 2-A b 1$ & $\mathrm{H}-2$ class II histocompatibility antigen, A beta chain & 3.68 & 9.22 & $\begin{array}{r}\text { Plasma membrane, } \\
\text { Lysosome }\end{array}$ & $\begin{array}{l}\text { Membrane, Single-pass } \\
\text { type I membrane protein }\end{array}$ \\
\hline- & MLV-related proviral Env polyprotein & 1.91 & 5.85 & $N / A$ & $\begin{array}{r}\text { Cell membrane, Virion } \\
\text { membrane }\end{array}$ \\
\hline Myadm & Myeloid-associated differentiation marker & 1.29 & 4.95 & $\mathrm{~N} / \mathrm{A}$ & $\begin{array}{r}\text { Cortical actin } \\
\text { cytoskeleton, Membrane, } \\
\text { Multi-pass membrane } \\
\text { protein }\end{array}$ \\
\hline Cox7a2 & Cytochrome c oxidase subunit 7A & 3.12 & 4.06 & $\begin{array}{r}\text { Mitochondrial inner } \\
\text { membrane }\end{array}$ & $\begin{array}{r}\text { Mitochondrion inner } \\
\text { membrane }\end{array}$ \\
\hline Tgm1 & Protein-glutamine gamma-glutamyltransferase $\mathrm{K}$ & -3.02 & 5.77 & Adherens junction & Membrane, Lipid-anchor \\
\hline Itgad & Integrin alpha-D & -2.08 & 3.47 & N/A & $\begin{array}{l}\text { Membrane, Single-pass } \\
\text { type I membrane protein }\end{array}$ \\
\hline
\end{tabular}


Supplementary Table 6: Significantly up/down-regulated proteins in the PM fraction of Marchf1 ${ }^{-/-}$B cells.

\begin{tabular}{|c|c|c|c|c|c|}
\hline Gene & Protein Names & $\begin{array}{l}\text { Log2 Fold } \\
\text { Change }\end{array}$ & $\begin{array}{l}-\log 10 p \\
\text { value }\end{array}$ & $\begin{array}{r}\text { Localisation } \\
\text { (based on GO-ID of } \\
\text { enrichment } \\
\text { analysis) }\end{array}$ & $\begin{array}{r}\text { Localisation } \\
\text { (based on UniProt) }\end{array}$ \\
\hline C3 & Complement C3 & 5.04 & 8.12 & $\begin{array}{r}\text { Extracellular, Cell } \\
\text { surface }\end{array}$ & $\begin{array}{r}\text { Extracellular region or } \\
\text { secreted }\end{array}$ \\
\hline- & MLV-related proviral Env polyprotein & 2.32 & 6.99 & $\mathrm{~N} / \mathrm{A}$ & $\begin{array}{r}\text { Cell membrane, Virion } \\
\text { membrane }\end{array}$ \\
\hline Cd86 & T-lymphocyte activation antigen CD86 & 3.49 & 6.18 & $\begin{array}{r}\text { Plasma membrane \& } \\
\text { intracellular membrane- } \\
\text { bounded organelle }\end{array}$ & $\begin{array}{r}\text { Cell membrane, Single- } \\
\text { pass type I membrane } \\
\text { protein }\end{array}$ \\
\hline$H 2-A b 1$ & $\begin{array}{l}\mathrm{H}-2 \text { class II histocompatibility antigen, A } \\
\text { beta chain }\end{array}$ & 2.07 & 5.98 & $\begin{array}{r}\text { Plasma membrane, } \\
\text { Lysosome }\end{array}$ & $\begin{array}{l}\text { Membrane, Single-pass } \\
\text { type I membrane protein }\end{array}$ \\
\hline$H 2-A a$ & $\begin{array}{l}\mathrm{H}-2 \text { class II histocompatibility antigen, A-B } \\
\text { alpha chain }\end{array}$ & 1.92 & 5.64 & $\begin{array}{l}\text { Plasma membrane, } \\
\text { Early endosome }\end{array}$ & $\begin{array}{l}\text { Membrane, Single-pass } \\
\text { type I membrane protein }\end{array}$ \\
\hline $\begin{array}{l}\text { Stk24; Stk25; } \\
\text { Stk26 }\end{array}$ & Serine/threonine-protein kinase 24/25/26 & 2.13 & 4.76 & $\mathrm{~N} / \mathrm{A}$ & Nucleus \\
\hline Anpep & Aminopeptidase $\mathrm{N}$ & 2.48 & 4.42 & Plasma membrane & $\begin{array}{r}\text { Cell membrane, Single- } \\
\text { pass type II membrane } \\
\text { protein }\end{array}$ \\
\hline Ahsg & Alpha-2-HS-glycoprotein & 2.29 & 4.32 & $\mathrm{~N} / \mathrm{A}$ & Secreted \\
\hline Lrch1 & $\begin{array}{l}\text { Leucine-rich repeat and calponin homology } \\
\text { domain-containing protein } 1\end{array}$ & 1.94 & 4.27 & $\mathrm{~N} / \mathrm{A}$ & Cytoplasm \\
\hline Ttc7a & Tetratricopeptide repeat protein 7A & 1.99 & 4.25 & $\mathrm{~N} / \mathrm{A}$ & $\begin{array}{r}\text { Cell membrane, } \\
\text { Cytoplasm }\end{array}$ \\
\hline
\end{tabular}




\begin{tabular}{|c|c|c|c|c|c|}
\hline$R p / 34$ & 60S ribosomal protein L34 & 2.63 & 4.22 & Mitochondrion & $\begin{array}{r}\text { Endoplasmic reticulum, } \\
\text { Cytosol }\end{array}$ \\
\hline Coro2a & Coronin-2A & 1.42 & 4.00 & Brush border & $\begin{array}{r}\text { Brush border, } \\
\text { Transcription repressor }\end{array}$ \\
\hline Sh3kbp1 & $\begin{array}{l}\text { SH3 domain-containing kinase-binding } \\
\text { protein } 1\end{array}$ & 2.08 & 3.84 & $\begin{array}{l}\text { Cell-cell junction, } \\
\text { Endocytic vesicle }\end{array}$ & $\begin{array}{r}\text { Cytoskeleton, } \\
\text { Cytoplasm }\end{array}$ \\
\hline Ifi30 & $\begin{array}{l}\text { Gamma-interferon-inducible lysosomal thiol } \\
\text { reductase }\end{array}$ & 2.60 & 3.83 & Lysosome & Lysosome \\
\hline Itgax & Integrin alpha-X & 2.65 & 3.83 & Plasma membrane & $\begin{array}{l}\text { Membrane, Single-pass } \\
\text { type I membrane protein }\end{array}$ \\
\hline$H b b-b 1 ; H b b-b 2$ & Hemoglobin subunit beta-1/2 & 2.11 & 3.68 & $\begin{array}{r}\text { Myelin sheath, } \\
\text { Haemoglobin complex }\end{array}$ & Cytosol \\
\hline Stk10 & Serine/threonine-protein kinase 10 & 1.63 & 3.58 & N/A & $\begin{array}{l}\text { Cell membrane, } \\
\text { Peripheral membrane }\end{array}$ \\
\hline Frmd8 & FERM domain-containing protein 8 & 1.56 & 3.55 & N/A & Cytosol, Cell membrane \\
\hline Taok3 & Serine/threonine-protein kinase TAO3 & 1.43 & 3.53 & $\mathrm{~N} / \mathrm{A}$ & Cytoplasm \\
\hline Git2 & ARF GTPase-activating protein GIT2 & 1.83 & 3.42 & Calyx of Held & Nucleoplasm \\
\hline Actr2 & Actin-related protein 2 & 1.18 & 3.36 & Cell cortex, Actin cap & Cytoskeleton, Nucleus \\
\hline Ptprj & $\begin{array}{l}\text { Receptor-type tyrosine-protein } \\
\text { phosphatase eta }\end{array}$ & 2.10 & 3.34 & $\begin{array}{l}\text { Immunol. synapse, } \\
\text { Plasma membrane, } \\
\text { Ruffle membrane }\end{array}$ & $\begin{array}{r}\text { Cell membrane, Single- } \\
\text { pass type I membrane } \\
\text { protein }\end{array}$ \\
\hline Ahrr & Aryl hydrocarbon receptor repressor & 2.23 & 3.34 & Nucleus & Nucleus \\
\hline Fam126a & Hyccin & 1.69 & 3.31 & Neuron projection & $\begin{array}{r}\text { Cytosol, Plasma } \\
\text { membrane }\end{array}$ \\
\hline Stxbp3 & Syntaxin-binding protein 3 & 1.16 & 3.29 & $\begin{array}{r}\text { Plasma membrane, } \\
\text { Apical plasma } \\
\text { Membrane, Cytosol }\end{array}$ & Cell membrane, Cytosol \\
\hline Gbp5 & Guanylate-binding protein 5 & 1.24 & 3.28 & Cytoplasmic vesicle & $\begin{array}{r}\text { Golgi apparatus } \\
\text { membrane, Cytoplasm }\end{array}$ \\
\hline
\end{tabular}




\begin{tabular}{|c|c|c|c|c|c|}
\hline Stxbp2 & Syntaxin-binding protein 2 & 1.34 & 3.15 & $\begin{array}{r}\text { Apical plasma } \\
\text { membrane, Phagocytic } \\
\text { vesicle, Zymogen } \\
\text { granule membrane }\end{array}$ & $\begin{array}{r}\text { Cytosol, azurophil } \\
\text { granule, apical plasma } \\
\text { membrane }\end{array}$ \\
\hline Cct8 & T-complex protein 1 subunit theta & 2.13 & 3.12 & $\begin{array}{r}\text { Cell body, Zona } \\
\text { pellucida receptor } \\
\text { complex, Chaperonin- } \\
\text { containing T-complex }\end{array}$ & $\begin{array}{r}\text { Cytoskeleton, } \\
\text { Cytoplasm }\end{array}$ \\
\hline Ap1m1 & AP-1 complex subunit mu-1 & 2.23 & 2.96 & $\mathrm{~N} / \mathrm{A}$ & $\begin{array}{r}\text { Golgi apparatus, } \\
\text { Peripheral membrane } \\
\text { protein }\end{array}$ \\
\hline Pacsin2 & $\begin{array}{l}\text { Protein kinase } \mathrm{C} \text { and casein kinase } \\
\text { substrate in neurons protein } 2\end{array}$ & 2.72 & 2.90 & $\begin{array}{r}\text { Cytoplasm, Cell-cell } \\
\text { junction, Cytosol, Trans- } \\
\text { Golgi network, Extrinsic } \\
\text { component of } \\
\text { membrane }\end{array}$ & $\begin{array}{r}\text { Ruffle membrane. } \\
\text { Peripheral membrane, } \\
\text { Cell membrane, Early } \\
\text { endosome, } \\
\text { Cytoskeleton }\end{array}$ \\
\hline lqgap1 & $\begin{array}{l}\text { Ras GTPase-activating-like protein } \\
\text { IQGAP1 }\end{array}$ & 1.00 & 2.89 & $\begin{array}{r}\text { Nucleus, Cytoplasm, } \\
\text { Cell-cell junction, Lateral } \\
\text { plasma membrane, } \\
\text { Neuron projection, Cell } \\
\text { leading edge, } \\
\text { Ribonucleoprotein } \\
\text { complex }\end{array}$ & $\begin{array}{l}\text { Nucleus, Plasma } \\
\text { membrane, Cytoplasm }\end{array}$ \\
\hline Agfg1 & $\begin{array}{l}\text { Arf-GAP domain and FG repeat-containing } \\
\text { protein } 1\end{array}$ & 2.18 & 2.85 & $\begin{array}{r}\text { Cytoplasmic vesicle, } \\
\text { Neuronal cell body, Cell } \\
\text { projection }\end{array}$ & $\begin{array}{r}\text { Nucleus, Cytoplasmic } \\
\text { vesicle }\end{array}$ \\
\hline $\mathrm{Hba}$ & Hemoglobin subunit alpha & 2.00 & 2.83 & Myelin sheath & $\begin{array}{r}\text { Cytosol, Extracellular } \\
\text { region or secreted, } \\
\text { Myelin sheath }\end{array}$ \\
\hline Tubgcp3 & Gamma-tubulin complex component 3 & 1.16 & 2.81 & $N / A$ & Centrosome \\
\hline Csk & Tyrosine-protein kinase CSK & 1.16 & 2.77 & Cell-cell junction & $\begin{array}{r}\text { Plasma membrane, } \\
\text { Cytoplasm }\end{array}$ \\
\hline
\end{tabular}




\begin{tabular}{|c|c|c|c|c|c|}
\hline Ap1b1 & AP-1 complex subunit beta-1 & 2.19 & 2.74 & N/A & $\begin{array}{r}\text { Golgi apparatus, } \\
\text { Peripheral membrane } \\
\text { protein }\end{array}$ \\
\hline Actr3 & Actin-related protein 3 & 1.14 & 2.73 & $\begin{array}{l}\text { Lamellipodium, Cell-cell } \\
\text { junction, Brush border }\end{array}$ & $\begin{array}{r}\text { Cytoskeleton, Nucleus, } \\
\text { Cell projection }\end{array}$ \\
\hline Ablim1 & Actin-binding LIM protein 1 & 1.22 & 2.73 & $\begin{array}{l}\text { Actin cytoskeleton, } \\
\text { Postsynaptic density }\end{array}$ & $\begin{array}{r}\text { Cytoskeleton, } \\
\text { Cytoplasm }\end{array}$ \\
\hline Ap2s1 & AP-2 complex subunit sigma & 1.35 & 2.71 & AP-2 adaptor complex & $\begin{array}{r}\text { Cell membrane, } \\
\text { Peripheral membrane } \\
\text { protein }\end{array}$ \\
\hline Eps15 & $\begin{array}{l}\text { Epidermal growth factor receptor substrate } \\
15\end{array}$ & 1.79 & 2.68 & $\begin{array}{r}\text { Plasma membrane, } \\
\text { Clathrin-coated } \\
\text { pit/vesicle, Ciliary } \\
\text { membrane, AP-2 } \\
\text { adaptor complex }\end{array}$ & $\begin{array}{r}\text { Cell membrane, } \\
\text { Peripheral membrane } \\
\text { protein, Cytoplasm, } \\
\text { Clathrin-coated pit }\end{array}$ \\
\hline Ccm2 & $\begin{array}{l}\text { Cerebral cavernous malformations protein } \\
2 \text { homolog }\end{array}$ & 1.43 & 2.66 & $\begin{array}{r}\text { Protein-containing } \\
\text { complex }\end{array}$ & Cytoplasm \\
\hline Fam65b & Protein FAM65B & 1.70 & 2.60 & Stereocilium & $\begin{array}{r}\text { Cytoskeleton, } \\
\text { Stereocilium membrane, } \\
\text { Apical cell membrane, } \\
\text { Cytoplasm }\end{array}$ \\
\hline Arpc2 & Actin-related protein $2 / 3$ complex subunit 2 & 1.02 & 2.53 & $\begin{array}{r}\text { Focal adhesion, Plasma } \\
\text { membrane, Synapse, } \\
\text { Endosome, Cell leading } \\
\text { edge, }\end{array}$ & $\begin{array}{r}\text { Nucleus, Cytoskeleton, } \\
\text { Cell projection }\end{array}$ \\
\hline Anxa6 & Annexin A6 & 1.99 & 2.52 & $\begin{array}{r}\text { Perinuclear region of } \\
\text { cytoplasm, Collagen- } \\
\text { containing extracellular } \\
\text { matrix }\end{array}$ & $\begin{array}{r}\text { Cytoplasm, } \\
\text { Melanosome }\end{array}$ \\
\hline Mpp6 & MAGUK p55 subfamily member 6 & 1.95 & 2.52 & Plasma membrane & $\begin{array}{r}\text { Membrane, Peripheral } \\
\text { membrane }\end{array}$ \\
\hline
\end{tabular}




\begin{tabular}{|c|c|c|c|c|c|}
\hline Gbas & Protein NipSnap homolog 2 & -3.07 & 4.79 & $\begin{array}{r}\text { Cytoplasm, } \\
\text { Mitochondrion }\end{array}$ & $\begin{array}{l}\text { Mitochondrion outer } \\
\text { membrane, Cytoplasm }\end{array}$ \\
\hline Slc25a1 & $\begin{array}{l}\text { Tricarboxylate transport protein, } \\
\text { mitochondrial }\end{array}$ & -2.75 & 3.68 & $\begin{array}{r}\text { Mitochondrion. } \\
\text { Mitochondrion inner } \\
\text { membrane }\end{array}$ & $\begin{array}{r}\text { Mitochondrion inner } \\
\text { membrane }\end{array}$ \\
\hline Sorl1 & Sortilin-related receptor & -2.15 & 3.48 & Nuclear envelope lumen & $\begin{array}{r}\text { Cell membrane, Single- } \\
\text { pass type I membrane } \\
\text { protein, Endosome, } \\
\text { Secreted, Golgi } \\
\text { apparatus membrane, } \\
\text { Endoplasmic reticulum } \\
\text { membrane, Secretory } \\
\text { vesicle membrane }\end{array}$ \\
\hline- & Ig lambda-1 chain $\mathrm{V}$ region & -1.99 & 3.39 & N/A & $\begin{array}{l}\text { Extracellular space, } \\
\text { Plasma membrane }\end{array}$ \\
\hline Sfxn3 & Sideroflexin-3 & -1.38 & 3.08 & Mitochondrion & $\begin{array}{r}\text { Mitochondrion } \\
\text { membrane }\end{array}$ \\
\hline Lmbrd1 & Probable lysosomal cobalamin transporter & -2.57 & 3.04 & $\begin{array}{l}\text { Plasma membrane, } \\
\text { Lysosome, Clathrin- } \\
\text { coated endocytic vesicle }\end{array}$ & Lysosome membrane \\
\hline Arl8b & ADP-ribosylation factor-like protein 8B & -1.24 & 3.04 & Synapse, Axon & $\begin{array}{r}\text { Late endosome } \\
\text { membrane, } \\
\text { Cytoskeleton, } \\
\text { Lysosome, Axon }\end{array}$ \\
\hline Fundc2 & FUN14 domain-containing protein 2 & -2.48 & 2.93 & N/A & $\begin{array}{r}\text { Mitochondrion. } \\
\text { Mitochondrion outer } \\
\text { membrane }\end{array}$ \\
\hline Ckap4 & Cytoskeleton-associated protein 4 & -1.22 & 2.85 & Endoplasmic reticulum & $\begin{array}{r}\text { Cytoskeleton, } \\
\text { Endoplasmic reticulum } \\
\text { membrane, Cell } \\
\text { membrane }\end{array}$ \\
\hline Mtco1 & Cytochrome c oxidase subunit 1 & -1.33 & 2.80 & $\begin{array}{r}\text { Mitochondrion inner } \\
\text { membrane }\end{array}$ & $\begin{array}{r}\text { Mitochondrion inner } \\
\text { membrane }\end{array}$ \\
\hline
\end{tabular}




\begin{tabular}{|c|c|c|c|c|c|}
\hline Hist1h1b & Histone H1.5 & -1.17 & 2.78 & $\mathrm{~N} / \mathrm{A}$ & Nucleus, Chromosome \\
\hline Hecs & Cytochrome c-type heme lyase & -2.23 & 2.58 & Mitochondrion & $\begin{array}{r}\text { Mitochondrion inner } \\
\text { membrane }\end{array}$ \\
\hline Mcur1 & Mitochondrial calcium uniporter regulator 1 & -1.64 & 2.55 & $\mathrm{~N} / \mathrm{A}$ & $\begin{array}{r}\text { Mitochondrion inner } \\
\text { membrane }\end{array}$ \\
\hline Ctss & Cathepsin S & -2.27 & 2.53 & Membrane, Lysosome & Secreted, Lysosome \\
\hline Rdh11 & Retinol dehydrogenase 11 & -1.55 & 2.52 & $\begin{array}{r}\text { Photoreceptor } \\
\text { inner/outer segment } \\
\text { membrane }\end{array}$ & $\begin{array}{r}\text { Endoplasmic reticulum } \\
\text { membrane }\end{array}$ \\
\hline
\end{tabular}


Supplementary Table 7: Significantly up/down-regulated proteins in the PM fraction of Marchf-/- B cells.

\begin{tabular}{|c|c|c|c|c|c|}
\hline Gene & Protein Names & $\begin{array}{l}\text { Log2 Fold } \\
\text { Change }\end{array}$ & $\begin{array}{l}-\log 10 p \\
\text { value }\end{array}$ & $\begin{array}{r}\text { Localisation } \\
\text { (based on GO-ID } \\
\text { of enrichment } \\
\text { analysis) }\end{array}$ & $\begin{array}{r}\text { Localisation } \\
\text { (based on } \\
\text { UniProt) }\end{array}$ \\
\hline Msn & Moesin & 1.50 & 15.24 & $\begin{array}{r}\text { Apical plasma } \\
\text { membrane, } \\
\text { Basolateral plasma } \\
\text { membrane, Apical part } \\
\text { of cell, Microvillus, } \\
\text { Myelin sheath }\end{array}$ & $\begin{array}{l}\text { Cytoskeleton, Plasma } \\
\text { membrane, Microvillus }\end{array}$ \\
\hline$R d x$ & Radixin & 1.81 & 10.32 & $\begin{array}{r}\text { Plasma membrane, } \\
\text { Lamellipodium, } \\
\text { Filopodium, Ruffle, } \\
\text { Apical part of cell, } \\
\text { Stereocilium, Cortical } \\
\text { actin cytoskeleton, } \\
\text { Microvillus, Myelin } \\
\text { sheath }\end{array}$ & $\begin{array}{r}\text { Cell membrane, } \\
\text { Cytoskeleton, } \\
\text { Microvillus }\end{array}$ \\
\hline Arcn1 & Coatomer subunit delta & 2.82 & 8.53 & $\begin{array}{r}\text { Golgi apparatus, } \\
\text { Endoplasmic } \\
\text { reticulum, COPI- } \\
\text { coated vesicle }\end{array}$ & $\begin{array}{r}\text { Golgi apparatus } \\
\text { membrane, peripheral } \\
\text { membrane protein, } \\
\text { Cytoplasm }\end{array}$ \\
\hline$D d b 1$ & DNA damage-binding protein 1 & 2.49 & 6.35 & N/A & Nucleus, Cytoplasm \\
\hline Prpf19 & Pre-mRNA-processing factor 19 & 2.17 & 5.80 & Nucleus & $\begin{array}{r}\text { Nucleus, Nucleoplasm, } \\
\text { Spindle }\end{array}$ \\
\hline Srrt & Serrate RNA effector molecule homolog & 2.39 & 5.38 & $\begin{array}{r}\text { Cytoplasm, } \\
\text { Nucleoplasm }\end{array}$ & $\begin{array}{r}\text { Cytoplasm, } \\
\text { Nucleoplasm }\end{array}$ \\
\hline
\end{tabular}




\begin{tabular}{|c|c|c|c|c|c|}
\hline$C d 1 d 1 ; C d 1 d 2$ & Antigen-presenting glycoprotein CD1d1/2 & 1.13 & 5.38 & $\begin{array}{r}\text { External side of } \\
\text { plasma membrane, } \\
\text { Endosome, Lysosome }\end{array}$ & $\begin{array}{l}\text { Cell membrane, } \\
\text { Endosome, Lysosome }\end{array}$ \\
\hline Rqcd1 & Cell differentiation protein RCD1 homolog & 1.46 & 4.86 & P-body & Nucleus, P-body \\
\hline Gk & Glycerol kinase & 1.61 & 4.02 & Mitochondrion & $\begin{array}{r}\text { Mitochondrion out } \\
\text { membrane }\end{array}$ \\
\hline Lamp1 & $\begin{array}{l}\text { Lysosome-associated membrane } \\
\text { glycoprotein } 1\end{array}$ & 1.99 & 3.98 & $\begin{array}{r}\text { External side of } \\
\text { plasma membrane, } \\
\text { sarcolemma, cell } \\
\text { surface, endosome, } \\
\text { endosome, lysosome, } \\
\text { phagocytic vesicle, } \\
\text { cytolytic granule, } \\
\text { synaptic vesicle, } \\
\text { vesicle, multivesicular } \\
\text { body, melanosome, } \\
\text { autolysosome, } \\
\text { phagolysosome } \\
\text { membrane }\end{array}$ & $\begin{array}{r}\text { Endosome membrane, } \\
\text { Lysosome membrane, } \\
\text { Cell membrane }\end{array}$ \\
\hline Psma4 & Proteasome subunit alpha type-4 & 2.79 & 3.82 & $\begin{array}{r}\text { P-body, Proteasome } \\
\text { core complex }\end{array}$ & Nucleus, Cytoplasm \\
\hline Ubtf & Nucleolar transcription factor 1 & 1.80 & 3.82 & Nucleolus & Nucleus \\
\hline Kars & Lysine-tRNA ligase & 1.72 & 3.80 & $\begin{array}{r}\text { Mitochondrion, } \\
\text { Aminoacyl-tRNA } \\
\text { synthetase } \\
\text { multienzyme complex }\end{array}$ & $\begin{array}{l}\text { Mitochondrion, } \\
\text { Cytoplasm, Nucleus, } \\
\text { Plasma membrane }\end{array}$ \\
\hline Pip4k2a & $\begin{array}{l}\text { Phosphatidylinositol 5-phosphate 4-kinase } \\
\text { type-2 alpha }\end{array}$ & 1.76 & 3.73 & N/A & $\begin{array}{r}\text { Nucleus, Plasma } \\
\text { membrane }\end{array}$ \\
\hline Kpnb1 & Importin subunit beta-1 & 1.50 & 3.42 & $\begin{array}{r}\text { Protein-containing } \\
\text { complex, Cytoplasmic } \\
\text { stress granule }\end{array}$ & Nucleus, Cytoplasm \\
\hline
\end{tabular}




\begin{tabular}{|c|c|c|c|c|c|}
\hline Tcp1 & T-complex protein 1 subunit alpha & 1.98 & 3.39 & $\begin{array}{r}\text { Golgi apparatus, } \\
\text { Microtubule organizing } \\
\text { center, Myelin sheath, } \\
\text { Cell body }\end{array}$ & $\begin{array}{r}\text { Cytoskeleton, Cytosol, } \\
\text { Golgi apparatus }\end{array}$ \\
\hline Khdrbs1 & $\begin{array}{l}\text { KH domain-containing, RNA-binding, } \\
\text { signal transduction-associated protein } 1\end{array}$ & 2.57 & 3.33 & Nucleus & Nucleus, Cytoplasm \\
\hline Copz1 & Coatomer subunit zeta-1 & 1.79 & 3.32 & N/A & $\begin{array}{r}\text { Golgi apparatus, } \\
\text { Cytoplasm }\end{array}$ \\
\hline Slc25a46 & Solute carrier family 25 member 46 & 3.06 & 3.32 & $\begin{array}{r}\text { Mitochondrion, } \\
\text { Mitochondrial outer } \\
\text { membrane }\end{array}$ & $\begin{array}{r}\text { Mitochondrial outer } \\
\text { membrane }\end{array}$ \\
\hline Actr1a & Alpha-centractin & 1.86 & 3.23 & Myelin sheath & $\begin{array}{r}\text { Cytoskeleton, } \\
\text { Centrosome }\end{array}$ \\
\hline Diablo & Diablo homolog, mitochondrial & 1.85 & 3.10 & $\begin{array}{r}\text { Cytoplasm, } \\
\text { Mitochondrion, } \\
\text { Cytoplasmic side of } \\
\text { plasma membrane, }\end{array}$ & Mitochondrion \\
\hline Frg1 & Protein FRG1 & 1.99 & 3.01 & N/A & Cajal body, Nucleolus \\
\hline Psmd2 & $\begin{array}{l}26 S \text { proteasome non-ATPase regulatory } \\
\text { subunit } 2\end{array}$ & 1.99 & 2.97 & $\begin{array}{r}\text { Proteasome accessory } \\
\text { complex, Proteasome } \\
\text { complex }\end{array}$ & $\begin{array}{r}\text { Cytoplasm, } \\
\text { Proteasome accessory } \\
\text { complex, }\end{array}$ \\
\hline$H 2 a f v ; H 2 a f z$ & Histone H2A.V; Histone H2A.Z & 1.15 & 2.87 & Nucleus & Nucleus \\
\hline Fam3a & Protein FAM3A & 1.83 & 2.80 & $\mathrm{~N} / \mathrm{A}$ & Secreted \\
\hline Cd6 & T-cell differentiation antigen CD6 & 1.61 & 2.80 & $\mathrm{~N} / \mathrm{A}$ & $\begin{array}{r}\text { Cell membrane, } \\
\text { Single-pass type I } \\
\text { membrane protein }\end{array}$ \\
\hline Srsf7 & Serine/arginine-rich splicing factor 7 & 2.33 & 2.79 & N/A & Nucleus, Cytoplasm \\
\hline Psmd11 & $\begin{array}{l}26 S \text { proteasome non-ATPase regulatory } \\
\text { subunit } 11\end{array}$ & 1.27 & 2.72 & $\begin{array}{r}\text { Proteasome accessory } \\
\text { complex }\end{array}$ & $\begin{array}{r}\text { Proteasome accessory } \\
\text { complex }\end{array}$ \\
\hline Arhgef6 & Rho guanine nucleotide exchange factor 6 & 1.59 & 2.71 & $\begin{array}{l}\text { Lamellipodium, Cell- } \\
\text { cell junction }\end{array}$ & Lamellipodium \\
\hline
\end{tabular}




\begin{tabular}{|c|c|c|c|c|c|}
\hline Spcs1 & Signal peptidase complex subunit 1 & 2.75 & 2.69 & $\mathrm{~N} / \mathrm{A}$ & $\begin{array}{l}\text { Microsome membrane, } \\
\text { Multi-pass membrane, } \\
\text { Endoplasmic reticulum }\end{array}$ \\
\hline Eif5a & Eukaryotic translation initiation factor $5 \mathrm{~A}-1$ & 1.81 & 2.66 & Nucleus, Cytoplasm & $\begin{array}{l}\text { Endoplasmic } \\
\text { reticulum, Nucleus }\end{array}$ \\
\hline Golga2 & Golgin subfamily A member 2 & 1.29 & 2.63 & $\begin{array}{l}\text { Golgi apparatus, Golgi } \\
\text { membrane, Spindle } \\
\text { pole, cis-Golgi network }\end{array}$ & $\begin{array}{r}\text { Golgi apparatus, } \\
\text { Spindle pole }\end{array}$ \\
\hline$R p / 37 a$ & $60 S$ ribosomal protein $\mathrm{L} 37 \mathrm{a}$ & 1.15 & 2.57 & $N / A$ & $\begin{array}{r}\text { Cytosol, Large } \\
\text { ribosomal subunit }\end{array}$ \\
\hline Hexa & Beta-hexosaminidase subunit alpha & 1.14 & 2.56 & Membrane, Lysosome & Lysosome \\
\hline Pgd & $\begin{array}{l}\text { 6-phosphogluconate dehydrogenase, } \\
\text { decarboxylating }\end{array}$ & 1.44 & 2.55 & $\mathrm{~N} / \mathrm{A}$ & $\begin{array}{r}\text { Golgi apparatus, } \\
\text { Endoplasmic } \\
\text { reticulum, Nucleus, } \\
\text { Secreted }\end{array}$ \\
\hline Erap1 & Endoplasmic reticulum aminopeptidase 1 & 1.09 & 2.52 & Cytoplasm & $\begin{array}{r}\text { Endoplasmic } \\
\text { reticulum, Single-pass } \\
\text { type II membrane } \\
\text { protein }\end{array}$ \\
\hline Pspc1 & Paraspeckle component 1 & 1.21 & 2.50 & $\begin{array}{l}\text { Nucleoplasm, } \\
\text { Paraspeckles }\end{array}$ & Nucleolus \\
\hline Prpsap1 & $\begin{array}{l}\text { Phosphoribosyl pyrophosphate synthase- } \\
\text { associated protein } 1\end{array}$ & 1.74 & 2.49 & $N / A$ & Cytoplasm \\
\hline Cd247 & T-cell surface glycoprotein CD3 zeta chain & 1.30 & 2.41 & $\begin{array}{l}\text { Alpha-beta T cell } \\
\text { receptor complex }\end{array}$ & $\begin{array}{l}\text { Cell membrane, } \\
\text { Single-pass type I } \\
\text { membrane protein }\end{array}$ \\
\hline Dek & Protein DEK & 1.22 & 2.38 & $\begin{array}{r}\text { Nucleus, Contractile } \\
\text { fiber }\end{array}$ & Nucleus \\
\hline- & Ig lambda-1 chain $\mathrm{C}$ region & -1.07 & 6.86 & & \\
\hline Ndufs5 & $\begin{array}{l}\text { NADH dehydrogenase [ubiquinone] iron- } \\
\text { sulfur protein } 5\end{array}$ & -1.07 & 6.31 & Mitochondrion & $\begin{array}{r}\text { Mitochondrial inner } \\
\text { membrane }\end{array}$ \\
\hline
\end{tabular}




\begin{tabular}{|c|c|c|c|c|c|}
\hline Rab35 & Ras-related protein Rab-35 & -1.16 & 5.48 & Mitochondrion & $\begin{array}{r}\text { Endosome, Plasma } \\
\text { membrane }\end{array}$ \\
\hline Atp5j & $\begin{array}{l}\text { ATP synthase-coupling factor } 6 \text {, } \\
\text { mitochondrial }\end{array}$ & -1.29 & 5.03 & $\begin{array}{r}\text { Mitochondrion, } \\
\text { Mitochondrial inner } \\
\text { membrane }\end{array}$ & $\begin{array}{r}\text { Mitochondrial inner } \\
\text { membrane }\end{array}$ \\
\hline Gnai3 & $\begin{array}{l}\text { Guanine nucleotide-binding protein } \mathrm{G}(\mathrm{k}) \\
\text { subunit alpha }\end{array}$ & -1.02 & 4.49 & $\begin{array}{r}\text { Cytoplasm, Golgi } \\
\text { apparatus }\end{array}$ & $\begin{array}{r}\text { Centrosome, Plasma } \\
\text { membrane }\end{array}$ \\
\hline Gngt2 & $\begin{array}{l}\text { Guanine nucleotide-binding protein } \\
G(I) / G(S) / G(O) \text { subunit gamma-T2 }\end{array}$ & -2.27 & 4.34 & $\mathrm{~N} / \mathrm{A}$ & Plasma membrane \\
\hline Gm10881 & Ig kappa chain $\mathrm{V}-\mathrm{V}$ region $\mathrm{L} 7$ & -1.72 & 3.67 & $\mathrm{~N} / \mathrm{A}$ & Secreted \\
\hline Cldnd1 & Claudin domain-containing protein 1 & -1.76 & 3.64 & $\begin{array}{r}\text { Apical plasma } \\
\text { membrane }\end{array}$ & $\begin{array}{r}\text { Multi-pass membrane } \\
\text { protein }\end{array}$ \\
\hline - & Ig kappa chain $\mathrm{C}$ region & -1.11 & 3.43 & & \\
\hline Fcer2 & $\begin{array}{l}\text { Low affinity immunoglobulin epsilon Fc } \\
\text { receptor }\end{array}$ & -1.11 & 3.19 & $\begin{array}{r}\text { External side of } \\
\text { plasma membrane }\end{array}$ & $\begin{array}{l}\text { Cell membrane, } \\
\text { Single-pass type I } \\
\text { membrane protein }\end{array}$ \\
\hline Pon2 & Serum paraoxonase/arylesterase 2 & -1.42 & 3.06 & $N / A$ & Membrane \\
\hline Ube2g 2 & Ubiquitin-conjugating enzyme E2 G2 & -1.57 & 3.02 & $\begin{array}{r}\text { Cytosol, Endoplasmic } \\
\text { reticulum }\end{array}$ & $\begin{array}{r}\text { Cytosol, Endoplasmic } \\
\text { reticulum }\end{array}$ \\
\hline- & Ig kappa chain V-V region MOPC 149 & -2.25 & 2.58 & & \\
\hline - & $\begin{array}{l}\text { Ig kappa chain V-III region ABPC 22/PC } \\
9245 / 4050 \text { region MOPC } 63\end{array}$ & -1.53 & 2.46 & & \\
\hline Syngr2 & Synaptogyrin-2 & -2.90 & 2.44 & Synaptic vesicle & $\begin{array}{r}\text { Cytoplasmic vesicle } \\
\text { membrane, Multi-pass } \\
\text { membrane protein }\end{array}$ \\
\hline Puf60 & Poly(U)-binding-splicing factor PUF60 & -2.00 & 2.41 & $\mathrm{~N} / \mathrm{A}$ & Nucleus \\
\hline Slc4a1 & Band 3 anion transport protein & -1.34 & 2.39 & $\begin{array}{r}\text { Plasma membrane, } \\
\text { basolateral plasma } \\
\text { membrane, cortical } \\
\text { cytoskeleton, }\end{array}$ & $\begin{array}{r}\text { Cell membrane, Multi- } \\
\text { pass membrane } \\
\text { protein }\end{array}$ \\
\hline
\end{tabular}


cytoplasmic side of

plasma membrane 